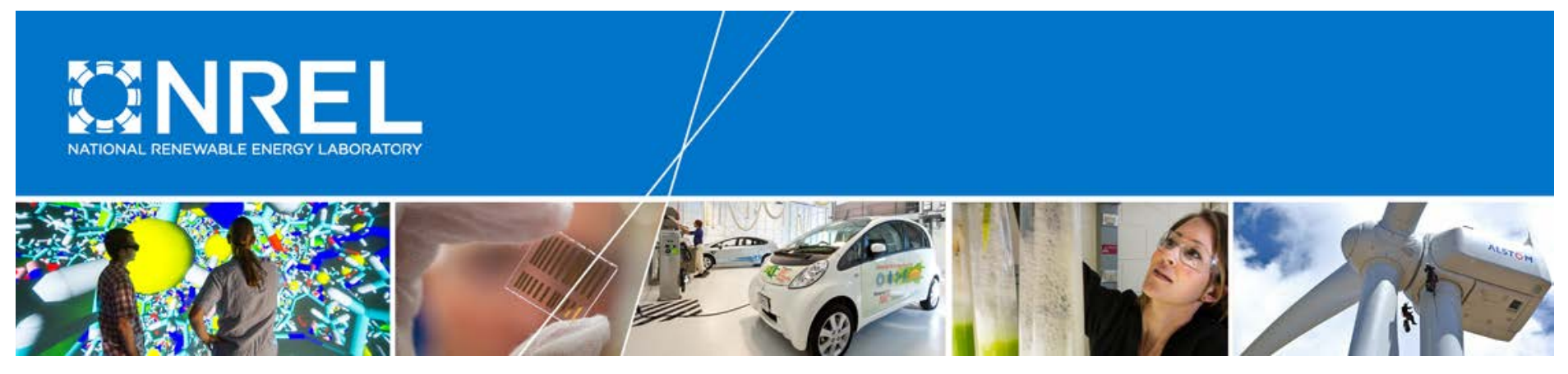

\title{
Native Vegetation Performance under a Solar PV Array at the National Wind Technology Center
}

Brenda Beatty, Jordan Macknick, James McCall, and Genevieve Braus National Renewable Energy Laboratory

David Buckner ESCO Associates Inc.

Link to Accompanying Zipped Data File (1.1 MB) at http://www.nrel.gov/docs/fy17osti/66218-1.zip

NREL is a national laboratory of the U.S. Department of Energy Office of Energy Efficiency \& Renewable Energy Operated by the Alliance for Sustainable Energy, LLC

This report is available at no cost from the National Renewable Energy Laboratory (NREL) at www.nrel.gov/publications.

Technical Report

NREL/TP-1900-66218

May 2017

Contract No. DE-AC36-08G028308 


\title{
Native Vegetation Performance under a Solar PV Array at the National Wind Technology Center
}

\author{
Brenda Beatty, Jordan Macknick, \\ James McCall, and Genevieve Braus \\ National Renewable Energy Laboratory \\ David Buckner \\ ESCO Associates Inc.
}

Prepared under Task No(s). SWEN.1000, ST6B.1100

NREL is a national laboratory of the U.S. Department of Energy Office of Energy Efficiency \& Renewable Energy Operated by the Alliance for Sustainable Energy, LLC

This report is available at no cost from the National Renewable Energy Laboratory (NREL) at www.nrel.gov/publications.

National Renewable Energy Laboratory 15013 Denver West Parkway Golden, CO 80401

303-275-3000 • www.nrel.gov

\section{Technical Report}

NREL/TP-1900-66218

May 2017

Contract No. DE-AC36-08GO28308 


\section{NOTICE}

This report was prepared as an account of work sponsored by an agency of the United States government. Neither the United States government nor any agency thereof, nor any of their employees, makes any warranty, express or implied, or assumes any legal liability or responsibility for the accuracy, completeness, or usefulness of any information, apparatus, product, or process disclosed, or represents that its use would not infringe privately owned rights. Reference herein to any specific commercial product, process, or service by trade name, trademark, manufacturer, or otherwise does not necessarily constitute or imply its endorsement, recommendation, or favoring by the United States government or any agency thereof. The views and opinions of authors expressed herein do not necessarily state or reflect those of the United States government or any agency thereof.

This report is available at no cost from the National Renewable Energy Laboratory (NREL) at www.nrel.gov/publications.

Available electronically at SciTech Connect http:/www.osti.gov/scitech

Available for a processing fee to U.S. Department of Energy and its contractors, in paper, from:

U.S. Department of Energy

Office of Scientific and Technical Information

P.O. Box 62

Oak Ridge, TN 37831-0062

OSTI http://www.osti.gov

Phone: 865.576.8401

Fax: 865.576.5728

Email: reports@osti.gov

Available for sale to the public, in paper, from:

U.S. Department of Commerce

National Technical Information Service

5301 Shawnee Road

Alexandria, VA 22312

NTIS http://www.ntis.gov

Phone: 800.553 .6847 or 703.605 .6000

Fax: 703.605.6900

Email: orders@ntis.gov 


\section{Acknowledgments}

This study was funded by the U.S. Department of Energy's (DOE's) Office of Energy Efficiency and Renewable Energy (EERE) and NREL's Solar Energy Analysis Office. The authors wish to thank the following individuals for their thoughtful comments, input, and review of the document in its various stages: Robert Margolis, Paul Denholm, Gretchen Waldenberg, and Tom Ryon (NREL), and Sujith Ravi (Temple University). In addition, the authors wish to thank SunEdison for their support in allowing us to set up the test plots beneath their solar array. We also wish to thank Kathryn Ruckman of NREL for her editorial support. 


\section{Table of Contents}

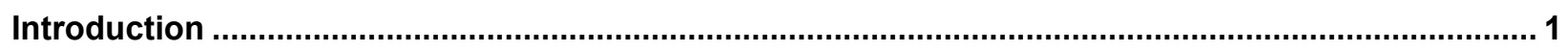

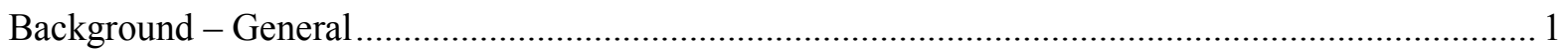

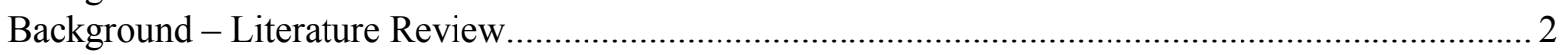

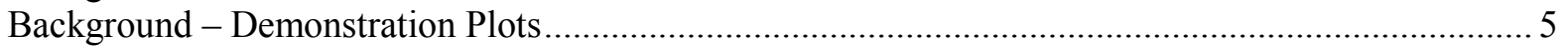

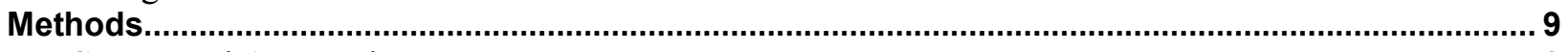

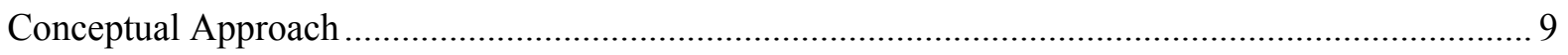

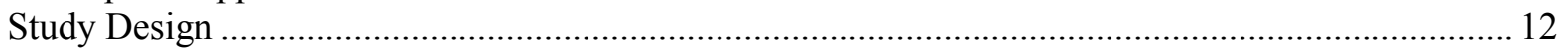

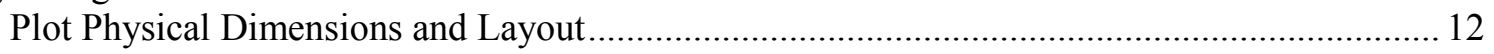

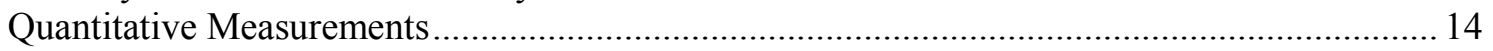

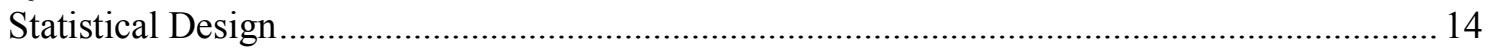

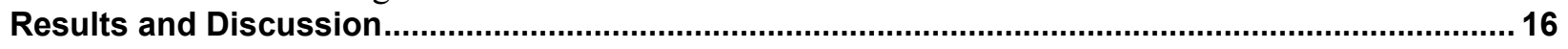

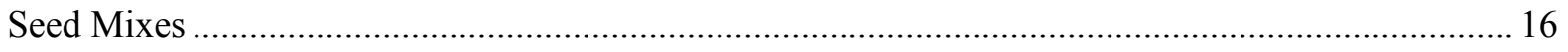

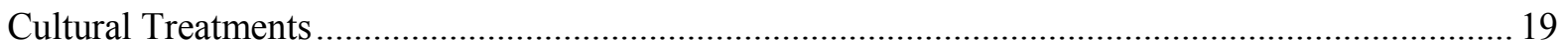

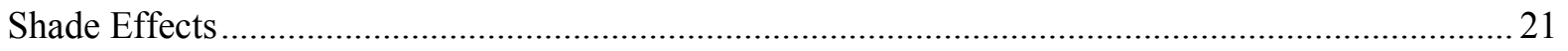

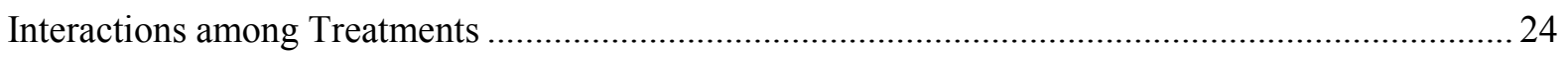

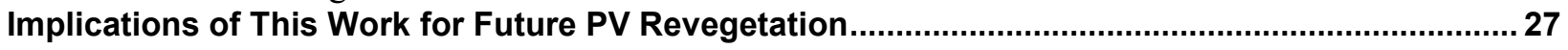

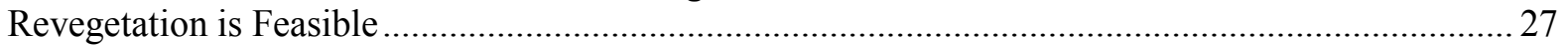

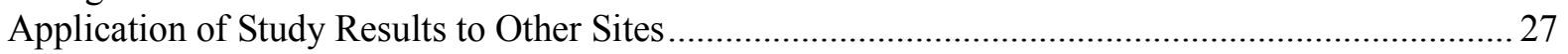

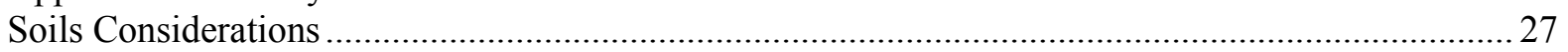

Limitations to Plant Growth Beneath Solar Arrays.............................................................. 28

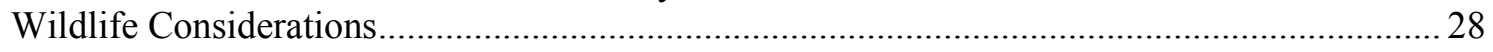

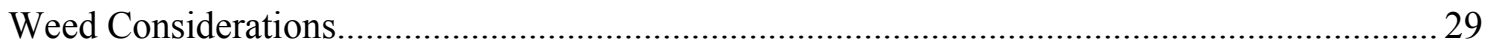

Impacts of Construction of Solar Arrays on the Ecology of Landscapes......................................... 29

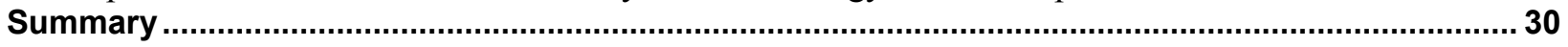

Appendix A

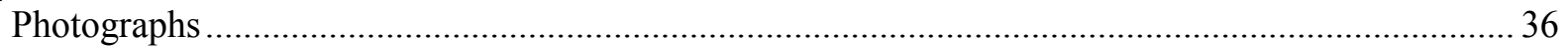

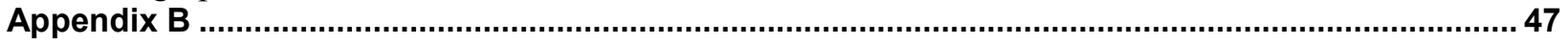

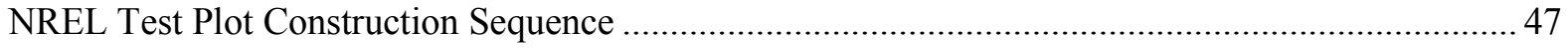




\section{List of Figures}

Figure 1. National Wind Technology Center (NWTC) showing location of PV array

Figure 2. Profile of collector configuration showing shading zone "treatments" used in this study (side view).

Figure 3. Profile of collector configuration showing shading zone "treatments" used in this study and conceptual rooting depths of warm-season grass (WSG) (seed mix: P1) and cool-season grass (CSG) (seed mix: P2) versus wedge of supplemental wetting from rain drip.

Figure 4. Plot layout - revegetation test plots. SunEdison PV array, National Wind Technology Center site, Jefferson Co., Colorado

Figure 5. Location of $0.5 \times 0.5 \mathrm{~m}$ percent cover assessment plots within each test plot (plan view)........ 14

Figure 6. Total vegetation cover (\%) by seed mix after three years ..................................................... 17

Figure 7. Total vegetation cover $(\%)$ by cultural treatment after three years ........................................... 20

Figure 8. Total Vegetation Cover (\%) by shading treatment after three years ...................................... 21

Figure 9. Analysis of NWTC precipitation data 2009 to 2012 with midnight to noon (a.m.) and noon to midnight (p.m.) data separated.

\section{List of Tables}

Table 1. Details of Seed Mixes.....

Table 2. Details of Cultural Treatments.

Table 3. Total Vegetation Cover (\%) by Seed Mix after Three Years.................................................... 17

Table 4. Total Vegetation Cover (\%) by Cultural Treatment after Three Years ........................................ 20

Table 5. Total Vegetation Cover (\%) by Shading Treatment after Three Years

\section{List of Appendices}

Appendices A and B are found at the end of this report (see Table of Contents).

The remaining appendices, listed below, can be found at http://www.nrel.gov/docs/fy17osti/66218-1.zip.

- Appendix C1. Seedling Density and Percent Cover Data 2010, National Wind Technology (NWTC) - SunEdison 1 Megawatt PV Array Vegetation Test Plots

- Appendix C2a. ANOVA output for July 2010 Seedling Density and Cover Data, National Wind Technology (NWTC) - SunEdison 1 Megawatt PV Array Vegetation Test Plots

- Appendix C2b. ANOVA output for August 2010 Percent Cover Data, National Wind Technology (NWTC) - SunEdison 1 Megawatt PV Array Vegetation Test Plots

- Appendix D1. Percent Cover Data for 2011, National Wind Technology (NWTC) - SunEdison 1 Megawatt PV Array Vegetation Test Plots

- Appendix D2. ANOVA output for 2011 Percent Cover Data, National Wind Technology (NWTC) - SunEdison 1 Megawatt PV Array Vegetation Test Plots

- Appendix E1. Percent Cover Data for 2012, National Wind Technology (NWTC) - SunEdison 1 Megawatt PV Array Vegetation Test Plots

- Appendix E2. ANOVA output for August 2012 Percent Cover Data, National Wind Technology (NWTC) - SunEdison 1 Megawatt PV Array Vegetation Test Plots [includes voluminous thirdlevel interaction statistics]

- Appendix F. ANOVA output for August 2012 Percent Cover Data, National Wind Technology (NWTC) - SunEdison 1 Megawatt PV Array Vegetation Test Plots 


\section{List of Photographs}

(in Appendix A)

Photograph 1. View of test plots directed south during June 2010. Matting treatment (A3) shown in foreground.

Photograph 2. Test Plots in June 2010. Foreground showing annual rye (Lolium multiflorum) nurse crop (A2); Midground showing matting treatment (A3); Background showing bare treatment (A1).

Photograph 3. Test Plots as of third year of growth (June 2012). Note extensive cover of grasses and paucity of cover directly beneath the panels. View faces south.

Photograph 4. Example of thunderstorm developing in late afternoon (as often is the case in late spring and summer - July 29, 2010). View faces west

Photograph 5. Native prairie forbs and subshrubs that were not seeded found their way onto the site and germinated (prairie coneflower, Ratibida columnifera)

Photograph 6. Native prairie forbs and subshrubs that were not seeded found their way onto the site and germinated (Porter's aster, Aster porteri)

Photograph 7. Native prairie forbs and subshrubs that were not seeded found their way onto the site and germinated (threadleaf groundseed, Senecio spartoides)

Photograph 8. Native prairie forbs and subshrubs that were not seeded found their way onto the site and germinated (fringed sagewort, Artemisia frigida)....

Photograph 9. Native prairie forbs and subshrubs that were not seeded found their way onto the site and germinated (snakeweed, Gutierrezia sarothrae).

Photograph 10. NWTC tracker arrays arranged in N-S rows that allow sun to reach the ground. Shading from ca. $1 / 4$ to slightly more than $1 / 2$ ground surface. The shaded area varies throughout the day. View faces south

Photograph 11. Fixed panel photovoltaic array at University of Colorado East Campus, arranged in east-west rows, maximizing shading effects. View faces west. 


\section{Introduction}

\section{Background - General}

The solar energy industry has seen rapid growth in the last several years. In the United States, total capacity of utility-scale solar installations was projected to increase by $123 \%$ (12 gigawatt [GW]) between year-end 2014 and year-end 2016 (EIA 2016, Hartmann et al. 2015). In the Department of Energy's (DOE's) Sunshot Vision Study goals, by the year 2030 solar energy capacity could be $329 \mathrm{GW}$, representing 14\% of national electricity generation (DOE 2012). Of the $329 \mathrm{GW}$ of solar projected to be installed in 2030, $121 \mathrm{GW}(37 \%)$ could be met by rooftop photovoltaics (PV). The remaining $208 \mathrm{GW}(63 \%)$ is projected to be met by ground-mounted PV $(181 \mathrm{GW})$ and concentrating solar power $(28 \mathrm{GW})$ installations (DOE 2012). Ground-mounted solar installations can require approximately 8 to 10 acres of land for every megawatt (MW) of capacity installed, depending on the technology and configuration (Ong et al. 2013). Given likely technology-specific development scenarios, land requirements for solar energy installations would be approximately 1.8 million acres in 2030 (Hartmann et al. 2015). This land use requirement represents less than $0.1 \%$ of the total surface area in the contiguous United States, and only one state (Rhode Island) is projected to have a land use requirement for solar that is greater than $1 \%$ of its land area (Hartmann et al. 2015). Despite the relatively small land requirements of solar energy development on a regional and national scale, there is growing concern over the land use impacts of solar energy development and cumulative impacts on ecosystems, habitat, and agricultural activities.

Construction activities at many utility-scale ground-mounted solar installations often include clearing and grubbing of soil and roots, topsoil stripping and stockpiling, land grading and leveling, and soil compaction. Existing vegetation that supports habitat is removed and any other vegetation is often discouraged; weeds and other unwanted vegetation are generally managed with herbicides and by covering the ground with gravel. These practices are generally employed to facilitate convenient construction access and facility operations. Despite these common practices, there are many opportunities to minimize the land use impacts of solar development and to incorporate vegetation into the design of solar installations (Macknick et al. 2013). The degree to which the loss of vegetation and other associated ecological impacts can be mitigated by of the inclusion of vegetation is a subject still in its infancy. Currently, the extent to which vegetation is considered in the construction and operation of solar energy is generally in the context of weed control, shading, and wildfire risk management (McPheeters and Vaughn 2011). As a result, implications for vegetation growth when large opaque objects such as solar collectors are placed between the sun and ground-level vegetation across large portions of earth surface have received little attention to date.

The present study seeks to address this void, advancing the state of knowledge of how constructed PV arrays affect ground-level environments, and to what degree plant cover, having acceptable characteristics within engineering constraints, can be re-established and thrive.

Beyond re-establishment of vegetation cover and the scope of this study is the evaluation of the degree to which replaced vegetation can support lost ecosystem functions such as wildlife cover, forage, travel corridors, trophic relationships, mycorrhizal associations, nutrient cycling, soil retention, and carbon sequestration (among other issues). These ecological features can be lost or strongly altered with the removal of vegetation cover and other conventional solar development activities. Given the potential land requirements of PV development in the United States (DOE 
2012, Hartmann et al. 2015), the amount of lost ecological function that can be regained among installations is a critically important subject. This is particularly true in the arid West, where natural recovery is slower than in more mesic environments because plant germination and establishment as well as growth rates are commonly limited by lack of moisture. Because the vegetation of North America, as well as the rest of the world, is highly variable, the loss of acreage under solar installations will be associated with differing site-specific ecological losses.

The objectives of this study are to (1) demonstrate the feasibility of successfully cultivating native vegetation underneath solar installations through demonstration plots, (2) provide methodological guidance for future demonstration plots to follow, and (3) discuss broader implications of vegetation opportunities for solar installations.

It is anticipated that results of the present study will be generally applicable to other grassland sites in the Great Plains, while project methodology and observed effects of shading may be more widely applicable to studies in other types of plant communities. This information can also be used by developers, state agencies, and environmental organizations to explore alternatives to ground-clearing when installing PV arrays.

\section{Background - Literature Review}

As discussed above, a literature search was performed to ascertain whether (1) re-establishing vegetation beneath constructed solar PV arrays, or (2) the impact of such construction on vegetation in general, had been addressed at other locations. At the time of the initial literature review (April 2010), these subjects had received minimal attention. Subsequent to the initial literature search being completed, more studies have addressed these topics. From the literature reviewed, there were six main topics discussed in the papers relating to utility scale solar development: (1) potential and observed environmental impacts, (2) hydrological impacts, (3) microclimate impacts under modules, (4) revegetation under models after disturbance, (5) land use impacts, and (6) co-location opportunities and case studies.

Since April 2010, there have been many studies that look at the potential and realized environmental impacts of utility scale solar installation. Lovich and Ennen (2011) examined the known and unknown environmental impacts during the construction, operation and maintenance, and decommissioning phases for solar installation (Lovich and Ennen 2011). Copeland, Pocewicz, and Kiesecker (2011) examined environmental impacts of energy development throughout the Western United States and promote large-scale planning efforts designed to meet energy demands while reducing impacts on sensitive wildlife species and habitats. Turney and Fthenakis (2011) identified and appraised 32 impacts from solar installation, under the themes of land-use intensity, human health and well-being, plant and animal life, geohydrological resources, and climate change. Northrup and Wittemyer (2013) examined likely impacts of solar installation and found that neither studies of environmental impacts or best practices of solar energy had been published to date.

Several other studies looked at specific impacts to biodiversity and natural habitat by utility-scale solar projects. The Renewable Energies Agency (2010) establishes guidelines for solar parks to protect biodiversity and habitats. These guidelines include prohibiting siting solar in environmentally protected areas, avoiding exposed sites, limiting impervious surfaces to less than $5 \%$ on site, prohibiting fence barriers to small animals, eliminating use of 
pesticides/fertilizers, and promoting sheep grazing rather than mowing operations (Renewable Energies Agency 2010). The Royal Society for the Protection of Birds (RSPB) (2014) lays out guidelines for protecting biodiversity in solar farms (RSPB 2014). Stoms, Dashiell, and Davis (2013) found a conflict between biodiversity conservation and solar siting and attempted to minimize biological impacts through development of a methodology that assigns a "compatibility factor" to sites, allowing for the prioritization of less biologically sensitive sites (Stoms, Dashiell, and Davis 2013). Both Hernandez et al. (2014) and Hernandez et al. (2015) express concerns about habitat fragmentation, land use cover changes, increased erosion and dust transport, impacts to biodiversity, and increased natural greenhouse gas (GHG) sequestration capacity. Also, they find that translocation and remediation of vegetation after a project is completed have less than a 20\% success rate (Hernandez et al. 2014; Hernandez et al. 2015).

From a hydrological perspective, Cook and McCuen (2013) studied water runoff of PV modules and found that runoff volumes increased with graveled or compacted ground underneath modules. Another finding from this study was that with well-maintained grass, PV modules do not have an impact on total volumes of runoff or peak discharge rates (Cook and McCuen 2013). In Marrou, Dufour, and Wery (2013) water flow and bulk actual evapotranspiration (AET) were measured in crops under PV modules by monitoring soil water content and soil water potential. The study found a $10 \%$ to $30 \%$ reduction in AET under modules compared to full sunlight, an effect mainly driven by shading (Marrou, Dufour, and Wery 2013). Dabney, Moore, and Locke (2006) found that conservation benefits are maximized when in-field and edge-of-field buffers are integrated with other conservation practices such as residue management and grade control structures, and that these buffers can improve both surface and subsurface water quality. Researchers find that water use efficiency could be increased by selecting crop species with rapid soil covering.

In studies related to microclimate impacts, conditions under PV modules were tested by monitoring air temperature, relative humidity, wind speed, soil temperature, crop temperature, and incident radiation in Marrou, Guilioni et al. (2013). Over the course of the experiment, the daily average air and crop temperature, relative humidity, and pressure deficit were comparable in shaded areas when compared to full sun plots. However, soil temperature was greatly reduced in the shaded treatments, and balance of incident radiation was different in shaded areas than in full sun (Marrou, Guilioni, et al. 2013).

The effects of microclimate conditions under PV systems on plant-soil carbon cycling were addressed by Armstrong et al. (2014) and Armstrong, Ostle, and Whitacker (2016). These studies indicated that PV arrays caused seasonal and diurnal variation in air and soil microclimate conditions to a magnitude that is known to affect terrestrial Carbon cycling. The studies also showed significant differences in above-ground biomass, plant diversity, and ecosystem carbon dioxide $\left(\mathrm{CO}_{2}\right)$ fluxes associated with the vegetation management and microclimate. Importantly, the studies highlighted that the understanding of microclimatic effects on solar installations is growing but currently incomplete, and the full effects on plant-soil carbon cycling, GHG emissions, and soil carbon stocks are under-studied (Armstrong et al. 2014; Armstrong, Ostle, and Whitaker 2016). De Marco et al. (2014) examined the impacts of utility-scale solar on local ecosystem services under two scenarios and find that siting can impact the vegetation providing ecosystem service climate regulation. 
Two studies looked at recommendations and case studies for reestablishing vegetation under modules after disturbance. Renewable Energies Agency (2010) looked at revegetation under modules for various case studies and recommended using a seed mixture appropriate for local site fauna to promote re-establishment of vegetation (Renewable Energies Agency 2010). Parker (2014) identified the need to examine local species for planting and sources for seeds to facilitate revegetation (BRE 2014).

Several studies examined the land use needed for solar energy and also the trade-offs of solar energy with other land use types. McDonald et al. (2009) examined land needed to comply with environmental regulations and laws (at the time of writing) along with how these regulations will impact land use changes in the United States (McDonald et al. 2009). Cameron, Cohen, and Morrison (2012) examined the synergy between renewable energy generation goals and biodiversity conservation in the Mojave Desert. In this study, the authors integrated spatial data on biodiversity conservation value, solar energy potential, and land surface slope angle and found that there is sufficient area to meet renewable energy goals without development on lands of relatively high conservation value (Cameron, Cohen, and Morrison 2012). Hernandez et al. (2014) studied the trade-offs and synergies of solar energy versus agricultural use and finds that $100 \%$ of the U.S. energy needs could be met with $11 \%$ of the nation's farmland (Hernandez et al. 2014). Hernandez et al. (2015) recommends siting solar modules in the built environment, colocation with agricultural, and use of lands on salt-degraded sites that have no value for agricultural use (Hernandez et al. 2015).

The concept of co-locating solar and agriculture was first laid out in Goetzberger and Zastrow (1982). In this study, the benefits of co-location along with calculations to determine the reduction in radiation underneath modules were laid out (Goetzberger and Zastrow 1982). Macknick, Beatty, and Hill (2013) built on the concept of co-location by studying the environmental impacts of utility-scale solar projects and how these impacts can be minimized through co-location of solar and vegetation/agriculture. Macknick, Beatty, and Hill (2013) also build on the benefits of co-location from an environmental and land use perspective (Macknick, Beatty, and Hill 2013). The Building Research Establishment (BRE) National Solar Centre report (2013) discusses how siting solar projects on previous agricultural land can provide a 25 year "rest" for the land, which can increase soil health and long term agricultural sustainability (BRE 2013).

Ravi et al. (2014) and Ravi et al. (2016) both explored "opportunities to co-locate solar infrastructures and agricultural crops to maximize the efficiency of land and water use" in both the United States and in India. These studies looked at the life cycle assessment for co-locating aloe crops under solar modules; water inputs for solar module cleaning are roughly equal to those for aloe cultivation. The studies find that co-locating aloe cultivation and solar systems can be economic in rural areas and may support electrification in regions of India. Also, these systems can create economic opportunities that are currently unavailable to people in these rural areas (Ravi et al. 2014, Ravi et al. 2016).

From an agricultural efficiency perspective of co-location, several studies examined impacts of shading on crops. Dupraz, Marrou et al. (2011) found that height of modules does not impact the quality of light reaching the modules' surface, but does impact the heterogeneity of radiation; modules closer to ground produced more heterogeneous radiation (Dupraz, Marrou, et al. 2011). 
Semchenko et al. (2012) found moderate shade had a positive impact on temperate grassland species and saw a reduction in mortality rates for $50 \%$ and $25 \%$ shade reductions; no negative impacts on plant growth and mortality rates were observed until light was reduced to $90 \%$ of full sun treatment (Semchenko et al. 2012). Dupraz, Talbot et al. (2011) found that co-locating solar and crops have between a 1.2 to 1.6 land equivalent ratio ( $>1$ demonstrates efficient land use) and that winter crops may not benefit from co-location, but shade can provide benefits to summer crops (Dupraz, Talbot, et al. 2011).

In a study from July 2010 to August 2011, Marrou, Wéry et al. (2013) conducted an experiment to compare the impact of three solar-panel shading densities on four different lettuce varieties over two years. During this study, researchers studied three different parameters: (1) productivity and radiation use efficiencies of lettuce varieties, (2) microclimates under PV modules, and (3) impacts of modules on water flows in crops and soil. Overall, the study found low to moderate impact on lettuce biomass growth for the summer and spring growing seasons. Two lettuce varieties tested showed more biomass production in the shade than in full sun. This study also found that biomass reduction was less than the overall light reduction, which shows that lettuce crops were able to improve the ability to intercept light in reduced light conditions (Marrou, Wéry, et al. 2013).

\section{Background - Demonstration Plots}

\section{Project Location and History}

This project study site is located at the National Renewable Energy Laboratory's (NREL's) National Wind Technology Center (NWTC). The NWTC is DOE's and the nation's principal research site for wind power and distributed energy resources, but the availability of large expanses of open land makes it suitable for solar development and research as well, as long as such facilities do not interfere with wind fetch (uninterrupted distance over which the wind blows without a significant change in direction) for onsite turbines.

In 2009, SunEdison, as a private venture, installed an eight-acre PV array at the NWTC to produce 1.1 MW of electrical power for sale to NREL (Figure 1). The PV array, located near the western edge of the NWTC, occupies land that previously supported native grassland vegetation. During installation of the PV array, most of the vegetation (approximately 7 acres) was removed and the area was graded to a less than $1 \%$ slope. The arrays are trackers, automatically moving throughout the day to track the progress of the sun across the sky, and are arranged in northsouth rows. They face east in morning and progressively tilt west throughout the day. The panels are approximately 1 meter $(\mathrm{m})$ above the ground surface (when level at noon). This comparatively low mounting height was partly driven by the need to resist very strong winds that are prevalent on this site, especially during winter. Had they been mounted higher, the shading effect on underlying vegetation would have been different. 
National Wind Technology Center, Jefferson County, Colorado

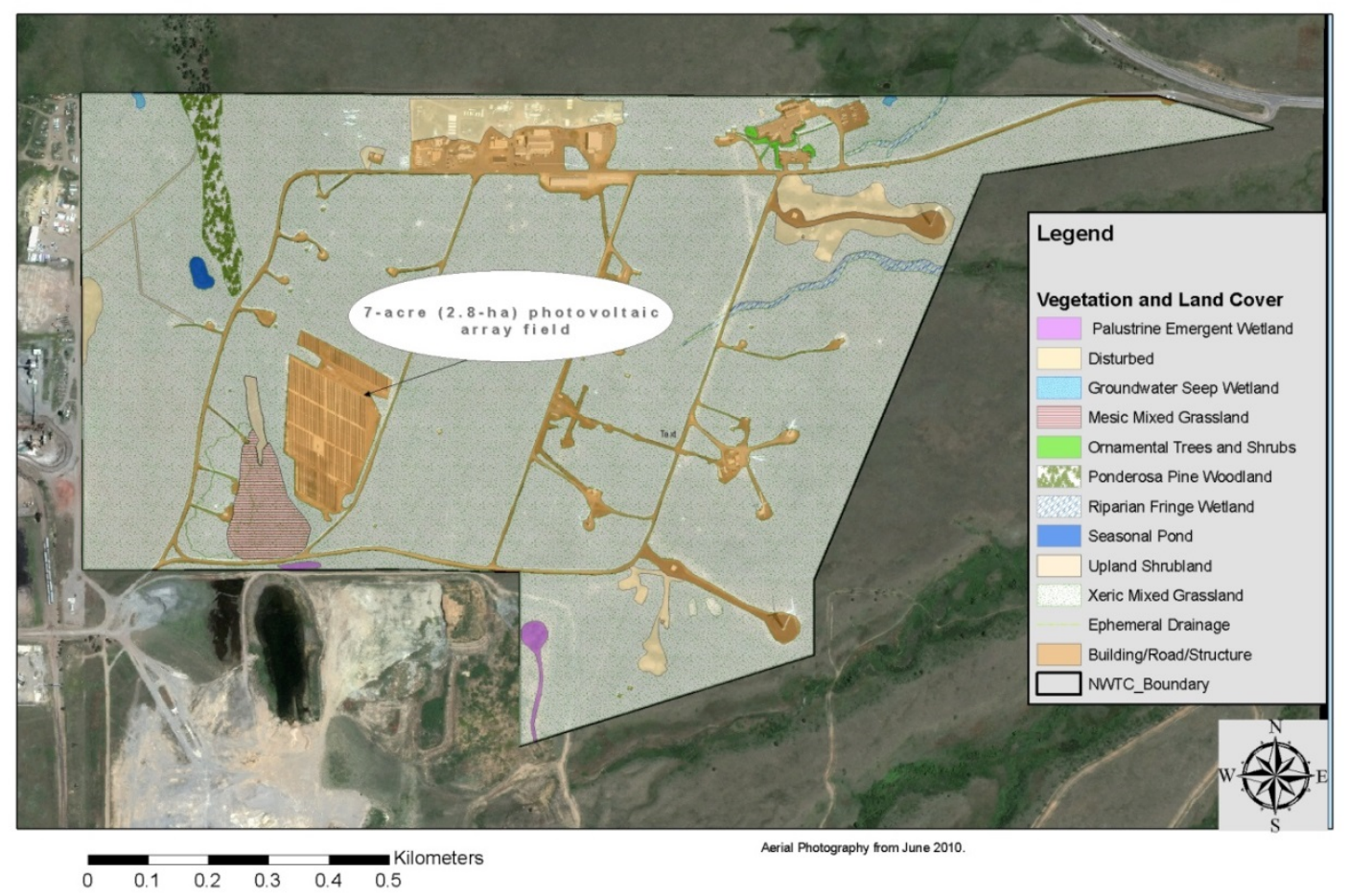

Figure 1. National Wind Technology Center (NWTC) showing location of PV array

Following installation, SunEdison was required to revegetate the disturbed area in accordance with NREL policies and procedures ${ }^{1}$, which include a recommended seed list for the site. However, the recommended seed mix was developed to address the construction of buildings, meteorological towers, and turbines, and thus included species environmentally adapted to fullsun conditions (i.e., heliophiles). Revegetation in this context would occur beneath a PV array having partially shaded conditions that would also potentially inhibit rainfall from reaching the soil. It was theorized that successful germination and growth could occur around the perimeter of the array or between rows of panels that are not shaded, while germination and growth success beneath the panels would be unlikely due to partial shading and inhibition of rainfall reaching the soil. In addition, NREL policies ${ }^{2}$ require demonstration of environmental stewardship on DOE property; this stewardship includes maintaining, protecting, and restoring natural environments to sustain natural and native ecological systems. Since the acreage beneath the PV array was graded, leveled, and compacted, the native ecological systems in that part of the site were substantially altered. Lacking site-specific information regarding revegetation under these types of disturbances, a literature search was conducted to discover what others have done in similar

\footnotetext{
${ }^{1}$ NREL procedure 6-1-29: Storm Water Pollution Prevention for Construction Activities: National Wind Technology Center

${ }^{2}$ NREL procedure 6-1.23: Natural Resource Conservation
} 
circumstances. At the time of the literature review at this project's inception (2010), it was discovered that very little information was available regarding seed mixes, soil amendments, and germination success at this kind of installation.

As a result of the paucity of useful information in the literature, a vegetation test-plot study was designed and implemented to obtain site-specific information that could be applied if additional PV arrays were installed at NREL. In addition, this information would likely be useful to others constructing PV arrays and desiring to restore vegetation, especially in the arid West.

\section{Site Physical Characteristics}

The demonstration test site is located along the east slope of the Front Range (eastern edge of the Central Rocky Mountains) in northern Jefferson County, Colorado, at the 305-acre NWTC, approximately 16 miles northwest of Denver. Elevation at the site is 6,060 feet (ft) $(1,848 \mathrm{~m})$. The site originally sloped at slightly greater than $2 \%$ to the east-northeast but during construction was graded to less than 1\% slope. Geomorphically it is part of a set of landforms that date from the late Pliocene to middle Pleistocene (1.5 to 2.2 Ma [million years before present]) (Malde 1955, Birkeland et al. 1996). Soils of the site are comprised of unsorted alluvial/colluvial debris in which soil-forming processes such as downward movement of clay particles and oxidation of native iron have progressed to uncommon extremes (Birkeland, et al. 1996).

The area has historically been occupied by xeric tallgrass prairie. This prairie existed on very old soils in a zone of relatively limited extent along the east slope of the Front Range of the Rocky Mountains in Colorado that had been spared the effects of regional erosion. In decades prior to construction, grazing and other various surface modifications had left the area altered from the xeric tallgrass condition. But the very old soils (paleosols) are still present with subsoils extremely red and very clay-enriched.

The test site area was mostly open grassland on less disturbed parts of the NWTC where big bluestem (Andropogon gerardii) predominated. It is subject to strong winds during winter and intense afternoon thunderstorms during late spring and summer. Total average annual precipitation at the site, based on NREL data from 1997 to 2012, is 14.7 inches (374 millimeters $[\mathrm{mm}])$. Average annual temperature is $50.0^{\circ} \mathrm{F}\left(10^{\circ} \mathrm{C}\right)$.

\section{Development of Mutual Study Objectives}

In designing the vegetation test-plot study, it became apparent that several stakeholders having different objectives would be involved in the project. Close collaboration among NREL biologists, safety personnel, and SunEdison engineers was an essential component of this successful undertaking and resulted in a study design that would meet all objectives. The resulting site-specific criteria to be met by this research project included the following:

\section{NREL Objectives:}

- Seed mix must include only native or adapted (noninvasive) species

- Seedlings must establish under existing precipitation, without supplemental water

- Plants must be drought-resistant upon maturity

- Plants must produce adequate cover to control wind and water erosion 
- Plants must create plant cover that could offer continued habitat value to wildlife using the site.

\section{SunEdison Objectives:}

- Seed mix should not include species that could grow taller than, twine with, or climb onto the solar collectors

- Plants must remain as short as possible to avoid touching electrical components.

\section{NREL and SunEdison Joint Objectives:}

- Seed mix should include spreading species that establish quickly to pre-empt undesirable, weedy species

- Plants must remain as short as possible (without mowing) to minimize the standing dead fuel load in case of wildfire.

Given the constraints on vegetation height, re-creation of the original xeric tallgrass vegetation was not possible. However, some of the species selected for the study were among those comprising at least some of the original onsite cover (blue grama [Bouteloua gracilis] and Canada bluegrass [Poa compressa]). 


\section{Methods}

\section{Conceptual Approach}

The conceptual approach used in designing the study plots included consideration of (1) the seed mix, (2) cultural treatments, and (3) shade effects.

\section{Seed Mixes}

Given the NREL goals for restoration of vegetation and the constraints identified by SunEdison management, an approach to revegetation was developed that included use of very short native grass species with known ability to sustain themselves through dry periods without intensive maintenance. Of primary use in this approach were blue grama and buffalograss (Buchloe dactyloides), the two species that comprise the bulk of cover and biomass in the shortgrass prairies of eastern Colorado. Both these species are warm-season (C4 photosynthetic pathway; see Sage and Monson 1999) heliophiles known for their abundance in open grasslands in the test site area and their relatively sparse occurrence in wooded areas where shading is common. Given the presence of the solar collectors and the associated shadows, it was uncertain whether shading beneath the collectors might exceed the shade tolerance of buffalograss and blue grama. Previous experience in the shadows of buildings had shown that both these species had limits to their tolerance of shade. Therefore, the test plots were designed to also include evaluation of shadetolerant grasses. The species selected for this role were Canada bluegrass and creeping red fescue (Festuca rubra). Both these species are cool-season (C3 photosynthetic pathway; see Sage and Monson 1999) species that are currently found in circumpolar distribution. Red fescue can tolerate deep shade and Canada bluegrass tolerates moderate shading. Both are rhizomatous and can spread to comprise an extensive ground cover that remains short (usually less than 18 inches [45 cm]). In addition to evaluation of sun-loving and shade-loving species separately, one treatment in the test plots included both species together in one mix. Virtually all grasses possess roots that are concentrated in the upper soil horizons (Weaver, J.E., 1919). Even blue grama and buffalograss have $90 \%$ of their root biomass in the upper 1 to $1.5 \mathrm{ft}$ of soil in most cases. However, total rooting depth of blue grama and buffalograss at 6 to $7 \mathrm{ft}$ (and greater) far exceeds the total rooting depths of Canada bluegrass and red fescue, which are no more than $2 \mathrm{ft}$ or occasionally slightly more (Weaver 1919) (Figure 3). C4 grasses like blue grama and buffalograss generally have biological processes that operate most effectively at higher temperatures than those corresponding processes in $\mathrm{C} 3$ grasses like Canada bluegrass and red fescue.

The specific seed mixes utilized, as along with their seeding rate, are shown in Table 1. 
Table 1. Details of Seed Mixes

\begin{tabular}{|c|c|c|}
\hline Planting Mixes & Species & $\begin{array}{c}\text { Rate } \\
\left(\text { avg. seeds per } \mathrm{ft}^{2}\right)\end{array}$ \\
\hline P1 & $\begin{array}{l}\text { Blue grama (Bouteloua gracilis, "Bad River"); } \\
\text { Buffalograss (Buchloe dactyloides "Cody”) }\end{array}$ & $\begin{array}{l}30 \\
15\end{array}$ \\
\hline P2 & $\begin{array}{l}\text { Canada bluegrass (Poa compressa "Canon"); } \\
\text { Creeping Red Fescue (Festuca rubra "Cindy Lou") }\end{array}$ & $\begin{array}{l}30 \\
30\end{array}$ \\
\hline P3 & $\begin{array}{l}\text { All species in P1 and P2: } \\
\text { Blue grama (Bouteloua gracilis, "Bad River"); } \\
\text { Buffalograss (Buchloe dactyloides "Cody") } \\
\text { Canada bluegrass (Poa compressa "Canon"); } \\
\text { Creeping Red Fescue (Festuca rubra "Cindy Lou") }\end{array}$ & $\begin{array}{l}20 \\
10 \\
10 \\
10\end{array}$ \\
\hline P4 & $\begin{array}{l}\text { All species in P3: } \\
\text { Blue grama (Bouteloua gracilis, "Bad River"); } \\
\text { Buffalograss (Buchloe dactyloides "Cody") } \\
\text { Canada bluegrass (Poa compressa "Canon"); } \\
\text { Creeping Red Fescue (Festuca rubra "Cindy Lou") } \\
\text { Plus: } \\
\text { American Vetch (Vicia americana VNS*) } \\
\text { Prairie Milkvetch (Astragalus laxmannii) } \\
\text { White Dutch Clover (Trifolium repens Common**) }\end{array}$ & $\begin{array}{c}20 \\
10 \\
10 \\
10 \\
\\
0.8 \\
0.8 \\
3\end{array}$ \\
\hline
\end{tabular}

$*$ VNS $=$ Variety not Stated $* *$ Common $=$ Seed of unspecified and undocumented variety

\section{Cultural Techniques}

Establishment of plants from seed necessitates careful planting techniques that ensure adequate seed-soil contact. In comparatively dry and windy regions such as central Colorado, seed left lying open on the soil surface is vulnerable not only to being blown away or eaten by animals but also is very unlikely to experience the continuing presence of moist conditions necessary to achieve germination and establishment. Beyond making sure that seed-soil contact is adequate, there were questions about how much, if any, additional protection might be needed. Therefore, three levels of cultural treatment were tested: (1) no additional protection (i.e., bare ground), (2) presence of a "nurse crop" (five seeds per square foot $\left[\mathrm{ft}^{2}\right]$ of annual ryegrass [Lolium multiflorum]) to shelter the seeds/seedlings, and (3) rolled matting of straw sewn with cotton thread (North American Green SB75BN). It should be noted that plastic mesh often used in the fabrication of matting was observed by the project team to entrap reptiles, exposing them to excessive heat, whereas the straw mat sewn with cotton thread is more flexible and allows them to escape.

The specific cultural treatments employed in this study are shown in Table 2. 
Table 2. Details of Cultural Treatments

\begin{tabular}{|c|l|l|}
\hline $\begin{array}{c}\text { Cultural } \\
\text { Treatments }\end{array}$ & \multicolumn{1}{|c|}{ Description } & \multicolumn{1}{|c|}{ Notes } \\
\hline A1 & No cultural treatment (bare soil) & $\begin{array}{l}\text { No additional seedling protection } \\
\text { beyond raking seed into soil }\end{array}$ \\
\hline A2 & Nurse crop & $\begin{array}{l}\text { Annual Rye }(\text { Lolium multiflorum } \\
\text { Common**) as nurse crop } \\
\text { Seed rate: } 5 \text { seeds/ft }\end{array}$ \\
\hline A3 & $\begin{array}{l}\text { Thin straw with natural fiber backing and } \\
\text { thread }\end{array}$ & $\begin{array}{l}\text { North American Green S75BN } \\
\text { no plastic mesh }\end{array}$ \\
\hline *VNS = Variety not Stated ** Common = Seed of unspecified and undocumented variety
\end{tabular}

\section{Shading Variation}

Within the test plots, the shadows of the PV collectors moved across the plot each sunny day. All portions of the plots were shaded at some point in the day. To assess the influence of shading on vegetation establishment, three variations of shading were identified. Collectors were constructed in north-south oriented rows, and thus, morning shade was most prevalent along the east edge of the plots (Figure 2). A center portion was most abundantly supplied with midday sun and the western portion was shaded the most in late day. Thus three shading "treatments" were identified: East, Middle, and West.
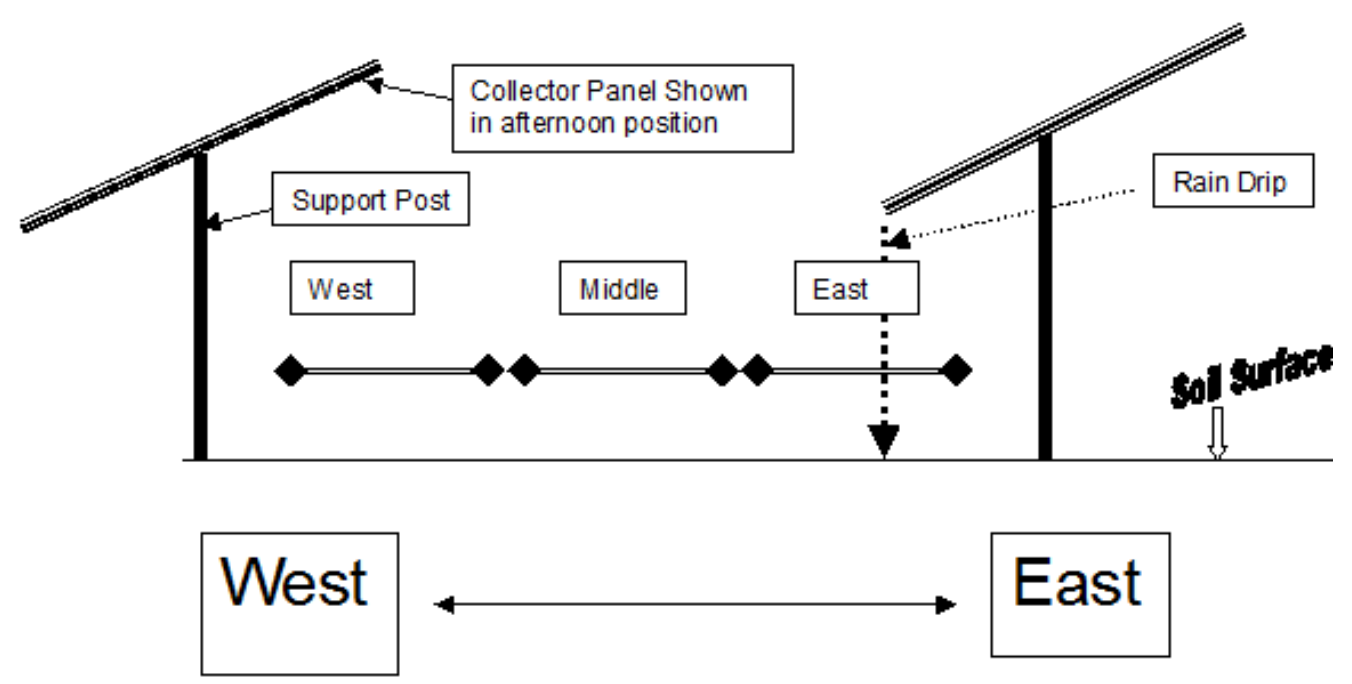

Figure 2. Profile of collector configuration showing shading zone "treatments" used in this study (side view). 

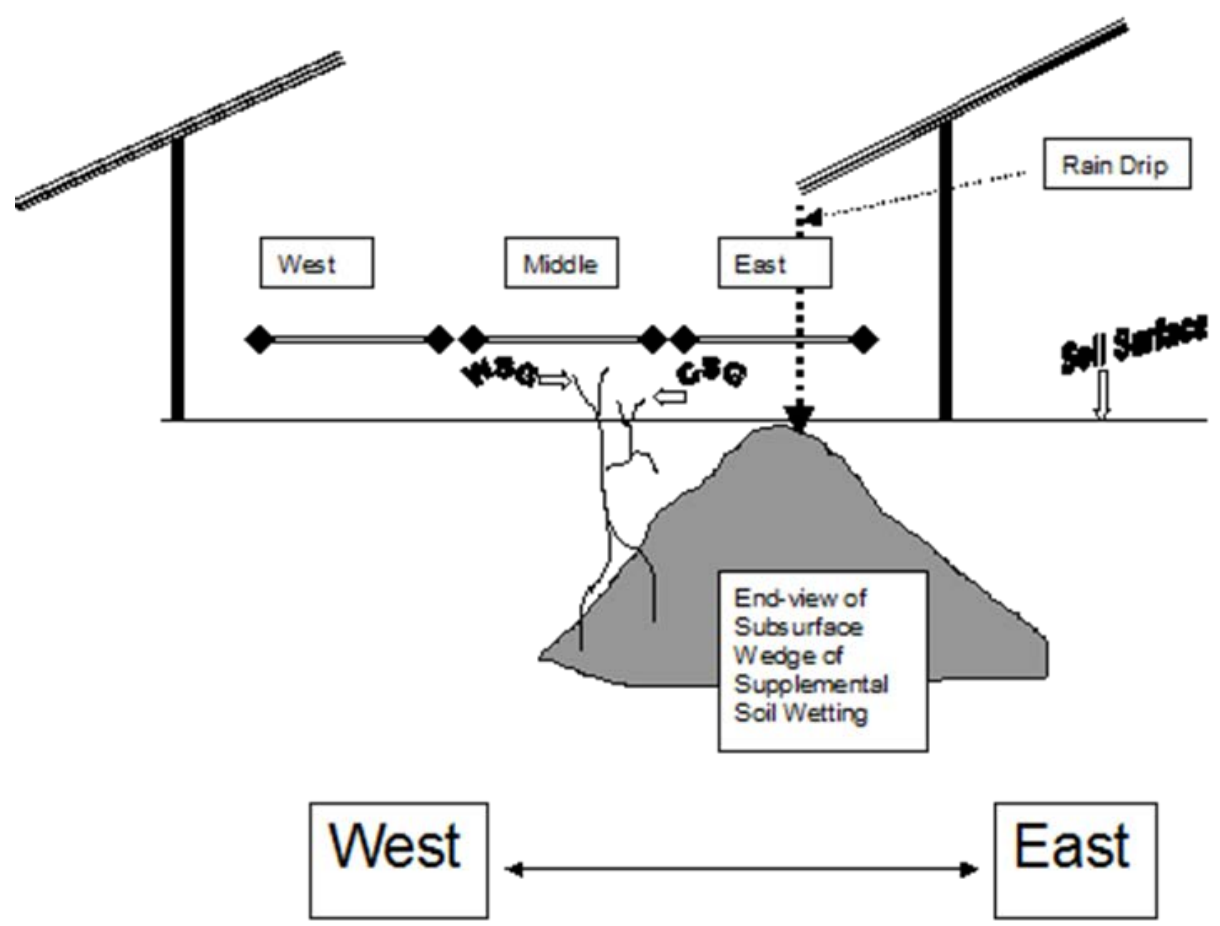

Figure 3. Profile of collector configuration showing shading zone "treatments" used in this study and conceptual rooting depths of warm-season grass (WSG) (seed mix: P1) and cool-season grass (CSG) (seed mix: P2) versus wedge of supplemental wetting from rain drip.

\section{Study Design}

\section{Plot Physical Dimensions and Layout}

Plots were parallelograms 13'1" x 9'4" that were 8'3" high (Figure 4 and Figure 5) and defined by the position of solar panel support posts. Arrangement of the plots within each of the four replication rows is shown in Figure 4. Within each of the four replication rows, the twelve-seed mix and cultural treatment combinations were randomly arranged, therefore arriving at a $4 \times 3$ factorial layout with four replications. This resulted in 48 test plots, each measuring approximately $13^{\prime}$ x 9' (totaling approximately 0.1 acres). Given the limited space in the gaps between rows of collectors and the overhang of the collectors, it was impossible to use drill seeders (the most common and practical means of seeding large areas). As a result, seeding in these plots was done by hand broadcast (followed by hand-harrowing with metal-tined rakes to enhance seed-soil contact). 


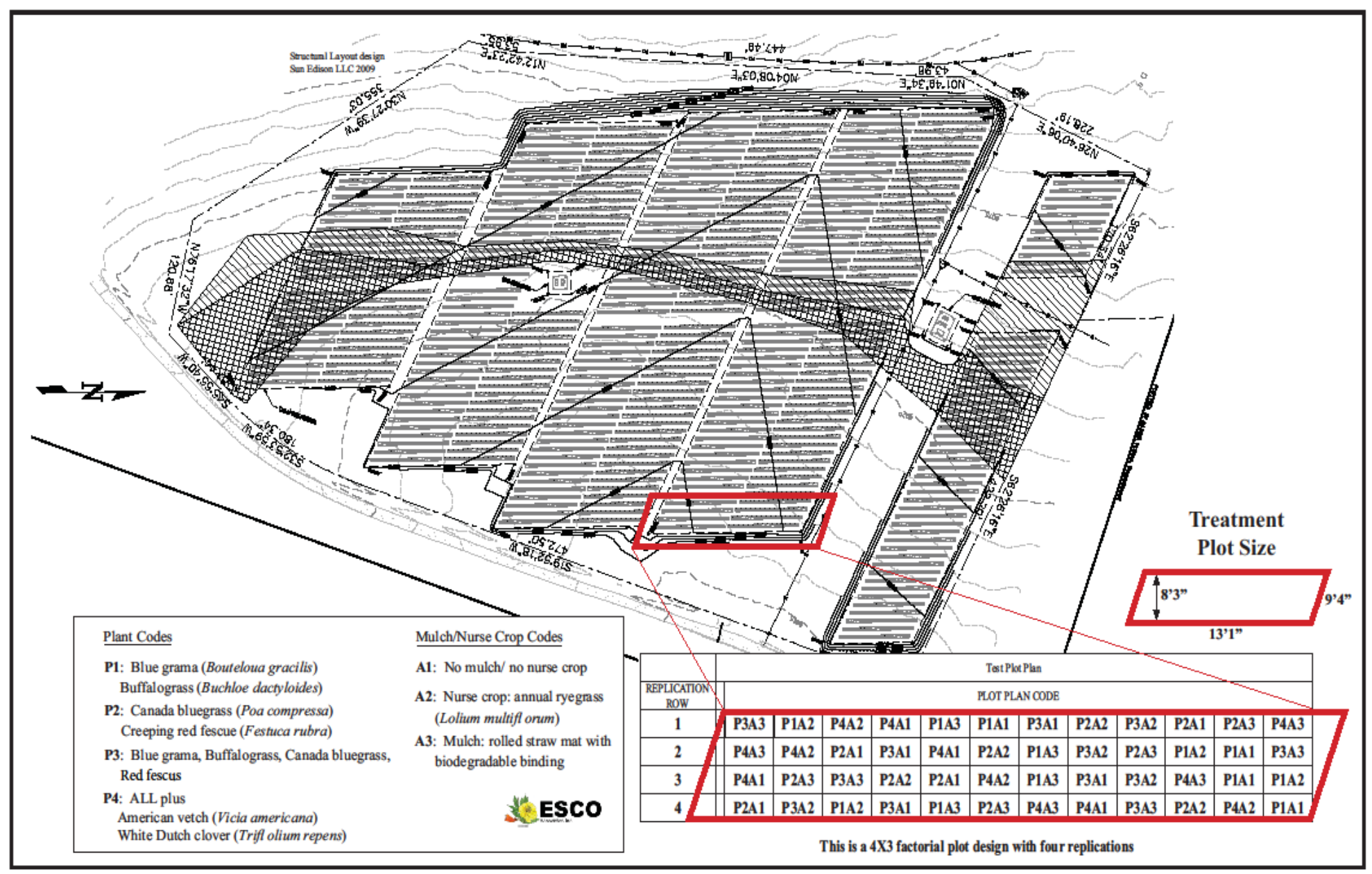

Figure 4. Plot layout - revegetation test plots. SunEdison PV array, National Wind Technology Center site, Jefferson Co., Colorado 
Details of the physical installation of the test plots are described in Appendix B.

\section{Quantitative Measurements}

During the first growing season, data on seedling density were collected to provide the earliest indication of germination success. These data were collected in 0.25 square meters $\left(\mathrm{m}^{2}\right)\left(2.7 \mathrm{ft}^{2}\right)$ plots on July 27 and 28, 2010. In addition, late summer (late August) assessment of vegetation cover was conducted in each plot in 2010,2011, and 2012. Visual estimates of the percentage of cover in each plot $(0.5 \times 0.5 \mathrm{~m})$ were made by species, to the nearest percent. Cover plot location within each test plot is shown in Figure 5.

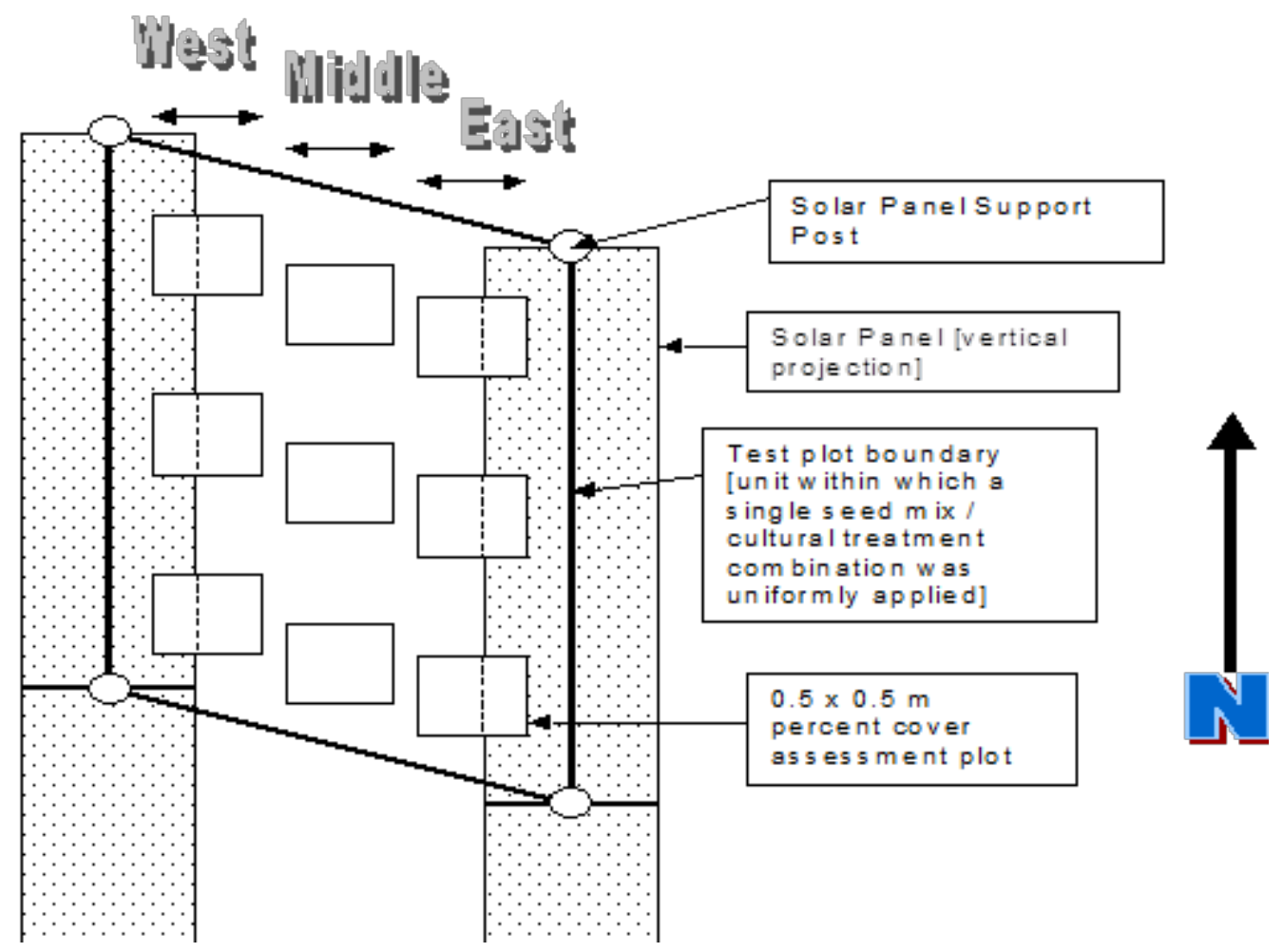

Figure 5. Location of $0.5 \times 0.5 \mathrm{~m}$ percent cover assessment plots within each test plot (plan view).

\section{Statistical Design}

The two-factor planting and cultural treatment plot design, in conjunction with the treatment of data from the three shading areas separately, allows for the use of three-way analysis of variance (ANOVA). ANOVA is a statistical method that allows for evaluation of the significance of means from the individual treatments and also allows evaluation of interactional effects (between treatments) and the significance of those interactions. It is conceptually similar to use of twosample t-tests, but allows simultaneous comparison of many means (Sokal and Rohlf 1969). 
Seedling density and cover data observations were categorized by Seed Mix, Cultural Treatment, Shading Treatment, and replication number. Cover data were then categorized as follows: Sun, Shade, Other Planted, Weeds, Rock/Litter, Volunteer, Native Volunteer, and Cover. A description of each of these variables follows:

$\underline{\text { Sun: }}$ Total vegetation cover for species in the Sun-loving seed mix (P1 seed mix)

Shade: Total vegetation cover for species in the Shade-loving seed mix (P2 seed mix)

Other Planted: Total vegetation cover for planted species not in the Sun- and Shade-loving seed mixes (i.e., the three legumes in the P4 seed mix)

$\underline{\text { Weeds: }}$ Total cover by noxious weed species (as per State of Colorado Lists A, B, or C)

Rock / Litter: Total rock and litter cover

Volunteer: Total vegetation cover for non-planted species including noxious weeds

Native Volunteer: Total vegetation cover for non-planted species not including noxious weeds

Cover: Total vegetation cover including noxious weeds.

Plant cover data were analyzed in R 2.12.1 software (R Development Core Team 2010) using 3way ANOVAs for the following models:

$$
\begin{aligned}
& \text { Sun } \sim \text { SeedMix*Treatment*Shading } \\
& \text { Shade } \sim \text { SeedMix*Treatment*Shading } \\
& \text { OtherPlanted } \sim \text { SeedMix*Treatment*Shading } \\
& \text { Weeds } \sim \text { SeedMix*Treatment*Shading } \\
& \text { NativeVolunteer } \sim \text { SeedMix*Treatment*Shading } \\
& \text { Volunteer } \sim \text { SeedMix*Treatment*Shading } \\
& \text { Cover } \sim \text { SeedMix*Treatment*Shading. }
\end{aligned}
$$

The R 2.12.1 software provides the traditional ANOVA breakdown of sum of squares variation and F-ratios with assessment of the probabilities of observing those calculated F-values. Beyond a simultaneous evaluation of the whole data set, R 2.12.1 offers the opportunity to assess significant differences between various pairs of treatment means (Tukey pairwise comparison). 


\section{Results and Discussion}

Results from the demonstration plots are shown by (1) seed mix, (2) cultural treatments, (3) shade effects, and (4) interactions among seed mixes, cultural treatments, and shade effects.

Data from 2010-2012 is contained in the appendices described below and may be found at http://www.nrel.gov/docs/fy17osti/66218-1.zip.

- Data from seedling density observations in the first growing season (2010) are presented in Appendix $\mathrm{C} 1$ and the results of ANOVA are presented in Appendix C2a.

- Data from cover measurements in 2010 are likewise presented in Appendix C1 and the ANOVA using these data is presented in Appendix C2b.

- Data from cover measurements in 2011 are presented in Appendix D1 and the ANOVA using these data is presented in Appendix D2.

- Data from cover measurements in 2012 are presented in Appendix E1 and the ANOVA using these data is presented in Appendix E2.

- ANOVA output files in Appendices C2, D2, and E2 are truncated because the tertiarylevel Tukey pairwise comparison is too voluminous and was not germane to discussions and conclusions here. Appendix F includes a full report of ANOVA output for the 2012 cover data and, therefore, is a much larger file than the others.

\section{Seed Mixes}

The warm-season grass mix (P1) had the highest seedling density from the earliest observations (July 2010) to the final observations (August 2012), with a total vegetation cover of 91.4\%. As of 2012 (the third year of the study), the cool-season grass mix (P2) was associated with the least total cover (61.8\%). By 2012, the mix of warm- and cool-season grasses (P3) was associated with $76.9 \%$ total cover, while the warm-season grass plus cool- season grass plus legume mix (P4) was associated with $74.8 \%$ total vegetation cover. These differences (except for that between $\mathrm{P} 3$ and $\mathrm{P} 4$ ) were significant at the $\mathrm{P}=0.001$ level. Results tabulated for Total Vegetation Cover at the end of year 3 are shown in Figure 6 and Table 3 below. 


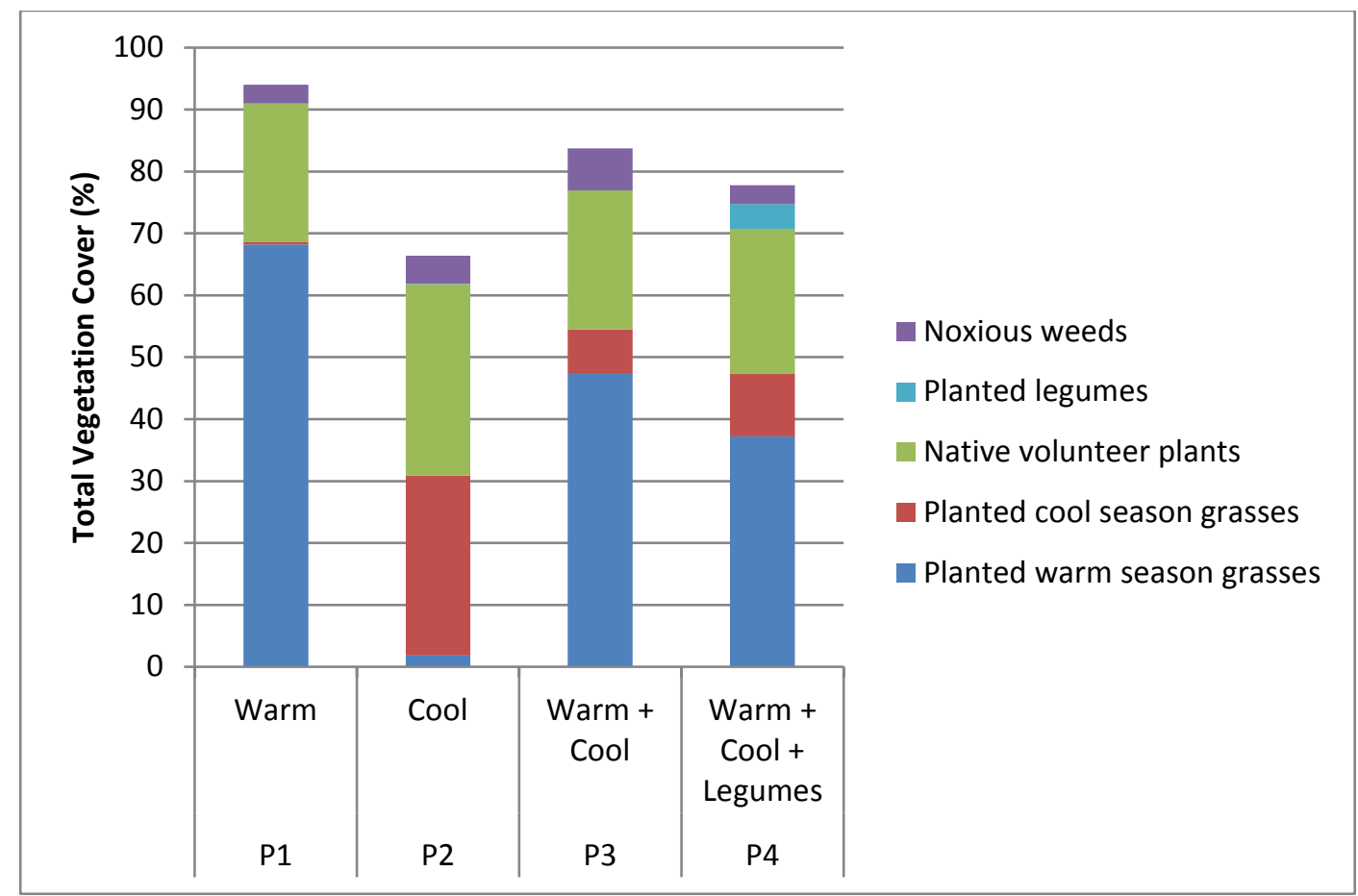

Figure 6. Total vegetation cover (\%) by seed mix after three years

Table 3. Total Vegetation Cover (\%) by Seed Mix after Three Years

\begin{tabular}{|l|c|c|c|c|}
\hline & P1 & P2 & P3 & P4 \\
Warm + & Cool & $\begin{array}{c}\text { Warm + Cool } \\
\text { + Legumes }\end{array}$ \\
\hline Planted warm-season grasses & 68.2 & 1.8 & 47.3 & 37.2 \\
\hline Planted cool-season grasses & 0.48 & 29.06 & 7.2 & 10.09 \\
\hline Native volunteer plants & 22.25 & 30.92 & 22.41 & 23.42 \\
\hline Planted legumes & 0.03 & 0.08 & 0.04 & 4.03 \\
\hline Noxious weeds & 3.08 & 4.52 & 6.77 & 3.06 \\
\hline $\begin{array}{l}\text { Total Cover (Including Noxious } \\
\text { Weeds) }\end{array}$ & 94.04 & 66.38 & 83.72 & 77.8 \\
\hline $\begin{array}{l}\text { Total Cover (Excluding) } \\
\text { Noxious Weeds) }\end{array}$ & $\mathbf{9 0 . 9 6}$ & $\mathbf{6 1 . 8 6}$ & $\mathbf{7 6 . 9 5}$ & $\mathbf{7 4 . 7 4}$ \\
\hline
\end{tabular}

In creating the greatest amount of overall vegetation cover, the sowing of the warm-season grasses buffalograss and blue grama (P1) (native species occurring onsite prior to disturbance) 
was the most effective treatment. Cool-season grasses (creeping red fescue and Canada bluegrass, P2) were unable to achieve the extensive cover that the warm-season grasses attained under the specific environmental conditions present beneath this particular PV collector configuration. When these warm- and cool-season grasses were sown in combination (P3), total vegetation cover was essentially the average of the levels of the warm- and cool-season grasses separately. The addition of legumes (P4) had no significant effect on total vegetation cover (mean cover over all cultural and shading treatments).

With regard to the abundance of the warm-season species, it is not surprising that areas seeded only with those species (P1) had the most cover by warm-season species (68.2\%). In other words, of the $91.4 \%$ total vegetation cover, $68.2 \%$ comprised warm-season grass cover and $23.2 \%$ was other species (mostly native volunteers). Regarding species occurring where they were not sown in this study, the existing soil may have had some residual seeds present or they may have blown in from nearby undisturbed areas. Likewise it is not surprising that very little cover by warm-season grasses $(1.8 \%)$ occurred in the treatment $(\mathrm{P} 2)$ that did not include warmseason grasses in the seed mix. Where both cool- and warm-season grasses were in the mix (P3) the warm-season grass result was $47.3 \%$ cover. Thus, the presence of cool-season grass in the mix reduced the cover of warm-seasons by about $30 \%$ of the warm-season only mix. Adding legumes to the mix further reduced warm-season grass cover to $37.2 \%$ (P4). These differences were all significant at the $\mathrm{P}=0.001$ level except $\mathrm{P} 3: \mathrm{P} 4$ which was significant at the $\mathrm{P}=0.01$ level.

The greatest success in establishing warm-season grass cover occurred when no other life forms were present. Addition of cool-season grasses in mix P3 coincided with a noticeable decline in vegetative cover (significant at $\mathrm{P}=0.001$ ) and the further addition of legumes (Mix P4) caused a further decline (which also was significant at $\mathrm{P}=0.001$ ). (Note that the extreme low value in seed mix P2 is attributable to the fact that no warm-season grasses were included in that mix.)

Regarding the abundance of cool-season species, in the treatment with them alone in the mix (P2) they comprised 29.1\% cover, while, expectedly, where they were not sown (P1 - warmseason only) the cover was only $0.5 \%$. For the cool-warm grass mix (P3), the cool-season cover was 7.2\% (in other words, the addition of warm-season grasses decreased the cover of coolseason grasses by about $75 \%$ ). Addition of legumes (P4) enhanced cool-season grass cover to $10.1 \%$, although this difference was only significant at the $\mathrm{P}=0.30$ level.

For cool-season grasses (Mix P2) it can be seen that addition of warm-season grasses (Mix P3) resulted in a decline in vegetative cover (significant at $\mathrm{P}=0.001$ ). Addition of legumes (Mix $\mathrm{P} 4$ ) ameliorated the decline somewhat but this difference was not significant statistically. (Note that the extreme low value in seed mix P1 is attributable to the fact that no cool-season grasses were included in that mix.)

Regarding the presence of legumes (P4), total vegetation cover was insignificantly different compared to that of the same mix but without legumes (P3).

When considering the establishment of noxious weeds it can be seen that the mix of cool- and warm-season grasses (P3) facilitated the establishment of opportunists most extensively. This difference was significant at the $\mathrm{P}=0.01$ level. Interestingly, addition of legumes to the same warm-cool grass mix (Mix P4) neutralized the noxious weed cover difference (significant at $\mathrm{P}=$ 
0.01). This latter effect may be reflective of increased competition for the noxious weeds that was offered by the legumes.

It should be noted that during each year of the 3-year study, state of Colorado noxious weeds (http://www.colorado.gov/cs/Satellite/ag_Conservation/CBON/1251618874438) were removed as required by law. The most active invading noxious weed species present was diffuse knapweed (Acosta diffusa). The knapweed was removed twice per year in late spring and early summer and so was never allowed to grow to the large size that would or could have affected the growth of the seeded species. Noxious weeds were removed by hand, not by use of herbicides.

The establishment of native volunteer plants (mostly forbs) proceeded most extensively where only cool-season grasses were planted. This is likely due to the fact that cool-season grasses planted by themselves produced the least cover and competition for resources for germinating native volunteers was lowest.

\section{Cultural Treatments}

The total vegetation cover supported after 3 years showed no significant difference between cultural treatments despite the first-year data on seedling density that showed significantly higher density in the matting treatment area (A3). Further, the presence of the annual rye nurse crop Lolium multiflorum (A2) was associated with lower total vegetation cover in year one, significantly greater cover in year two, and no significant difference by year three. It should be pointed out that the Lolium nurse crop was present in 2010 and was nearly absent thereafter because it is an annual that almost never successfully reseeds itself in Colorado environments. Results tabulated for Total Vegetation Cover are shown in Figure 7 and Table 4. 


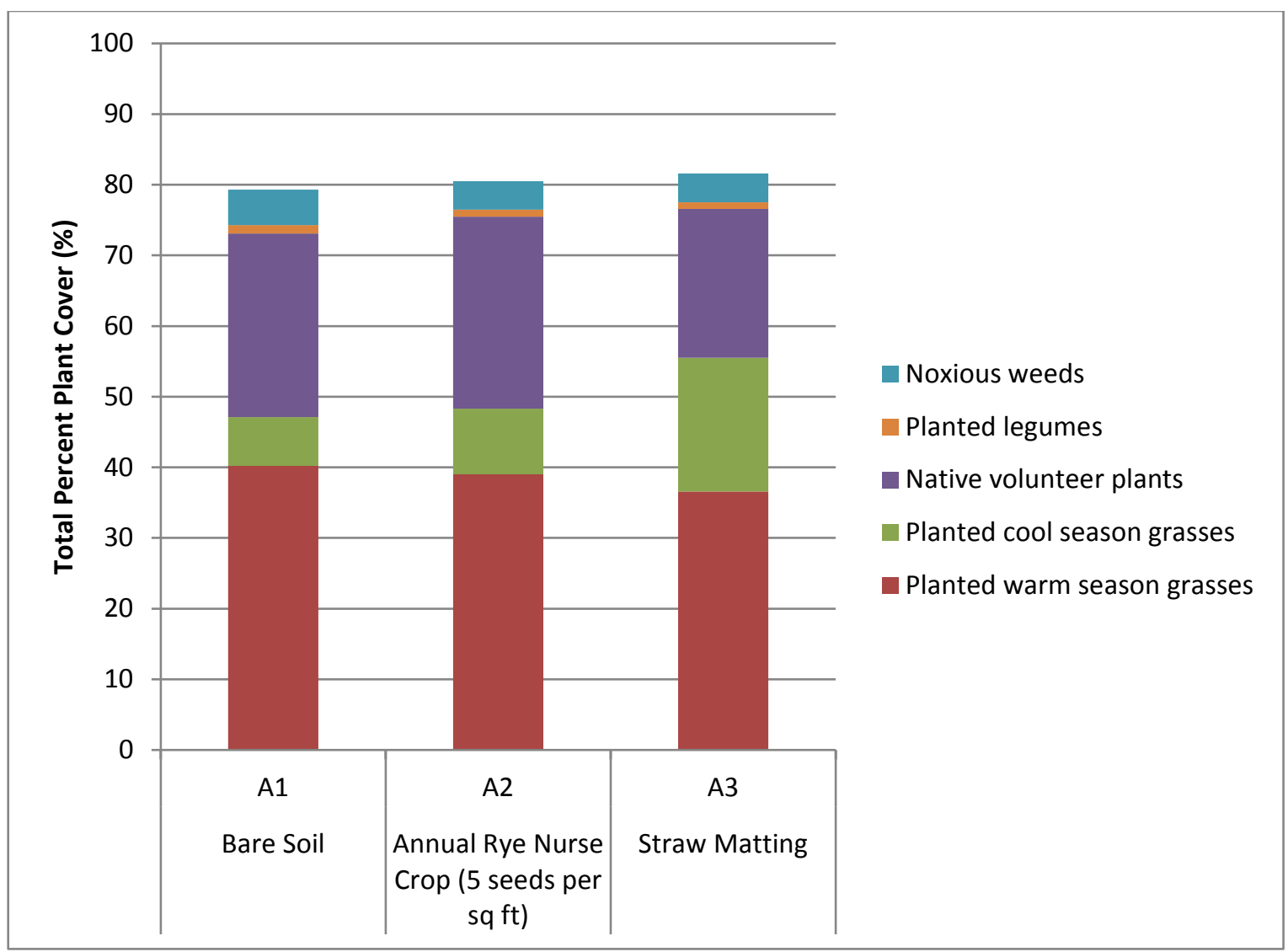

Figure 7. Total vegetation cover (\%) by cultural treatment after three years

Table 4. Total Vegetation Cover (\%) by Cultural Treatment after Three Years

\begin{tabular}{|l|c|c|c|}
\hline & Bare Soil & $\begin{array}{c}\text { Annual Rye Nurse } \\
\text { Crop (5 seeds per } \\
\text { sq ft) }\end{array}$ & $\begin{array}{c}\text { Straw } \\
\text { Matting }\end{array}$ \\
\hline Planted warm-season grasses & A1 & A2 & A3 \\
\hline Planted cool-season grasses & 40.2 & 39 & 36.6 \\
\hline Native volunteer plants & 6.9 & 9.3 & 18.9 \\
\hline Planted legumes & 26 & 27.2 & 21.1 \\
\hline Noxious weeds & 1.2 & 1 & 0.9 \\
\hline & 5 & 4 & 4.1 \\
\hline Total Cover (Including Noxious Weeds) & 79.3 & 80.5 & 81.6 \\
\hline Total Cover (Excluding Noxious Weeds) & $\mathbf{7 4 . 3}$ & $\mathbf{7 6 . 5}$ & $\mathbf{7 7 . 5}$ \\
\hline
\end{tabular}

Although by 2012 (the third year of growth) there was no significant overall difference between cultural treatments, a significant difference had existed in 2010 and 2011. In those years, the treatment with Lolium multiflorum had significantly greater total vegetation cover, probably 
largely because of the Lolium cover in 2010. But by 2011, when the Lolium was nearly absent (it is an annual grass that does not significantly reseed in this region), a significantly greater total plant cover was still present. The exact nature of this positive residual effect and why it disappeared in 2012 is not known.

The only significant differences in third-year cover related to cultural treatment, shown in the table above, are that cool-season grass cover was greatly enhanced by the use of matting $(\mathrm{P}=0.001)$ and establishment of native volunteer plants was depressed by matting $(\mathrm{P}=0.05)$.

\section{Shade Effects}

The tracking feature of the PV collectors in conjunction with diurnal asymmetry in the incidence of rain during late spring and summer leaves the East subplots substantially better supplied with moisture (Figure 2 and Figure 3). It is thought that the differential effect of precipitation draining off the collectors is a spring and summer phenomenon. Snow that has fallen on the collectors is thought to be equally likely to be shed in both directions. The enhancement of moisture conditions in the East subplots is reflected in the fact that total vegetation cover as of 2012 was $84.2 \%$ in the East subplots compared to $77.7 \%$ in the Middle subplots and $66.9 \%$ in the West subplots. The difference between the East subplots and the others was significant at the $\mathrm{P}=0.001$ level in 2012. This effect was not apparent in 2010 but became apparent in 2011, at which time it was significant at the $\mathrm{P}=0.01$ level. This is likely due to the fact that 2010 was a period of seedling establishment during which time plants do not produce much above-ground growth. Seedling density data from 2010 actually showed that the Middle areas had the highest numbers of seedlings. Thus, enhanced moisture may have been a smaller factor at that point than warmth (the Middle plots experiencing the greatest exposure to direct sunlight). Results tabulated for Total Vegetation Cover resulting from shading effects are shown in Figure 8 and Table 5.

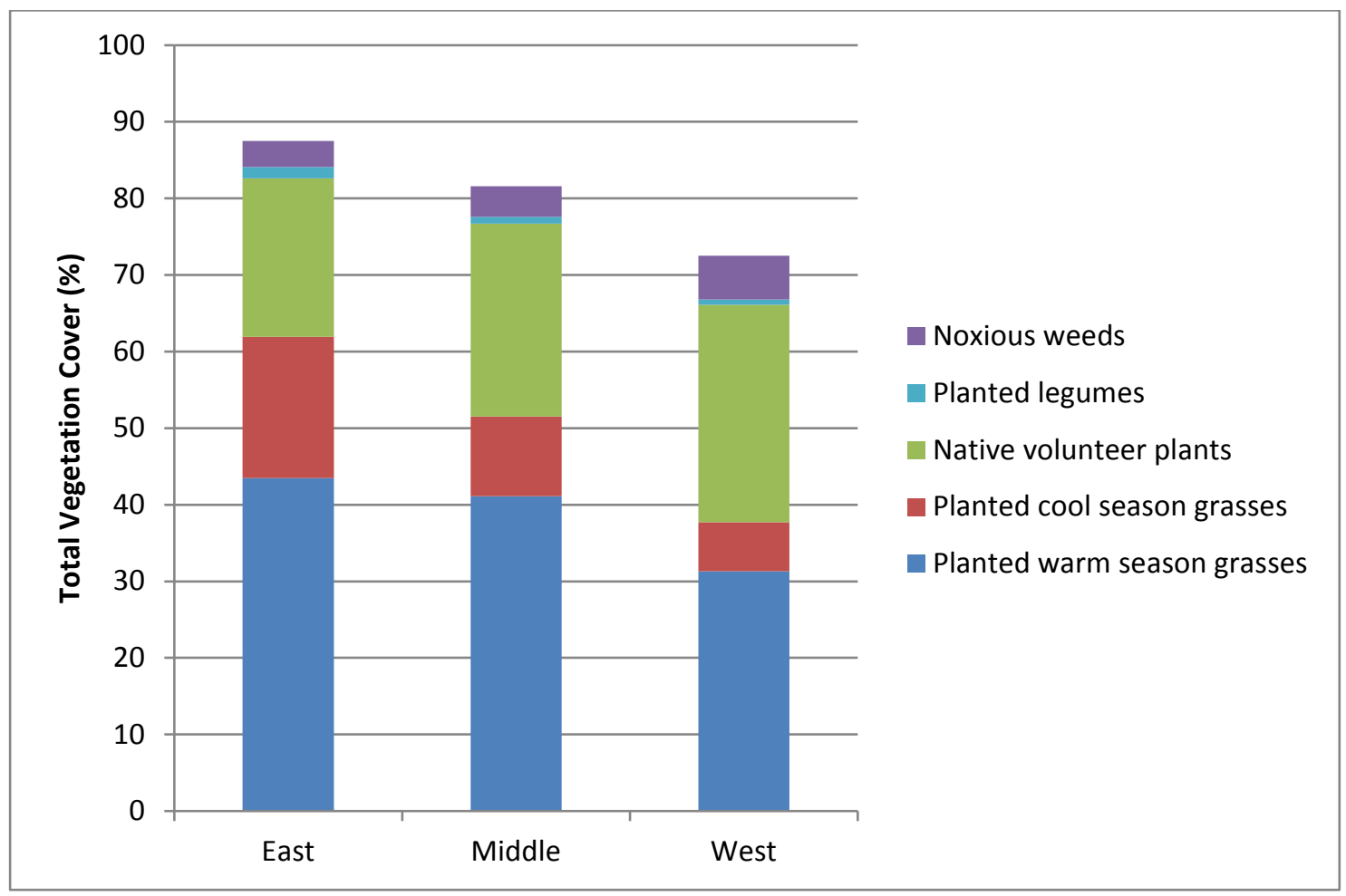

Figure 8. Total vegetation cover (\%) by shading treatment after three years 
Table 5. Total Vegetation Cover (\%) by Shading Treatment after Three Years

\begin{tabular}{|c|c|c|c|}
\hline & East & Middle & West \\
\hline Planted warm-season grasses & 43.5 & 41.1 & 31.3 \\
\hline Planted cool-season grasses & 18.4 & 10.4 & 6.4 \\
\hline Native volunteer plants & 20.7 & 25.2 & 28.4 \\
\hline Planted legumes & 1.5 & 0.9 & 0.7 \\
\hline Noxious weeds & 3.4 & 4 & 5.7 \\
\hline $\begin{array}{c}\text { Total Cover (Including Noxious } \\
\text { Weeds) }\end{array}$ & 87.5 & 81.6 & 72.5 \\
\hline Total Cover (Excluding) Noxious \\
Weeds)
\end{tabular}

Statistical evaluation of the data indicate that both the East and Middle treatments were significantly greater in warm-season grass cover than the West treatment $(\mathrm{P}=0.001)$ but that the difference between East and Middle was not significant.

Statistical evaluation of these data on cool-season grass cover shows differences between East and Middle and also between East and West treatments at the $\mathrm{P}=0.001$ level. Difference between the Middle and West treatments was significant but only at the $\mathrm{P}=0.1$ level.

Cover by native volunteer plant species (mostly forbs) was greatest $(\mathrm{P}=0.01)$ in the West treatment likely because competition was least there (i.e., least cover by warm- and cool-season grasses, as discussed above). For similar reason, cover by noxious weeds (see Table 5) was greatest in the West treatment $(\mathrm{P}=0.1)$. Planted legumes showed the opposite pattern (see Table $5)$ with greatest cover $(\mathrm{P}=0.1)$ in the East subplots.

Consistent with the fact that both warm-season grass cover and cool-season grass cover were least present in the West treatment it is not surprising to see that noxious weed establishment was greatest in the West treatment $(\mathrm{P}=0.01)$. Weeds are opportunists, and where the least growth of perennial plants occurs, the opportunities are greatest.

It is important to understand that, in addition to the duration of shadows beneath the collectors, the tracking movement of the collectors from east-tipped (morning) to west-tipped (afternoon) had an important environmental effect in the form of interaction with local weather patterns. During most of late spring and summer in this area of Colorado, mornings tend to be clear or at least rainless and afternoons are substantially more likely to experience buildup of thunderstorm clouds (Photograph 4), frequently accompanied by rain (see analysis of NREL onsite precipitation data in Figure 9). Accordingly, the East, Middle, and West subplots vary from each other in sun exposure and moisture, as described below and illustrated in Figure 8:

East - These areas are shaded in mornings and would be sun-exposed in afternoon but for the fact that afternoons are very often cloudy during the period of June through August. Perhaps 
most importantly, if afternoon rains occur, as often is the case during the June through August period, the collectors are tipped west and shed water onto the ground beneath which is the location of the East subplots (refer to Figure 4). Therefore, these subplots during summer get both relief from baking afternoon sun and, often, direct input of supplemental moisture.

Middle - These areas are shaded in earliest morning but get direct sun through the middle of the day and no supplemental moisture shed from the collectors.

West - These areas get direct sun in morning and are shaded in afternoon by the collectors. They do not get supplemental water from the collectors during summer because most rainfall events during that period are in the afternoon and the collectors divert rain to the eastern portion of the next row to the west. Rains in the morning (that would be shed onto these subplots) are uncommon during the summer.

An interesting pattern emerges from these latter two batches of data. The warm-season grasses in the Middle treatment may be able to benefit from the extra moisture delivered to the East area by the west-tilted collectors, but the cool-season grasses appear to receive much less benefit. This could reflect the likely difference in rooting depths. The likely deeper roots of the warm-season grasses may have access to the "wedge" of supplemental wetting extending outward below ground. Shallower roots of cool-season grasses would have much less access to this underground moisture (see illustration of this concept in Figure 3).

\section{Precipitation Accumulated May 15 - Aug 15}

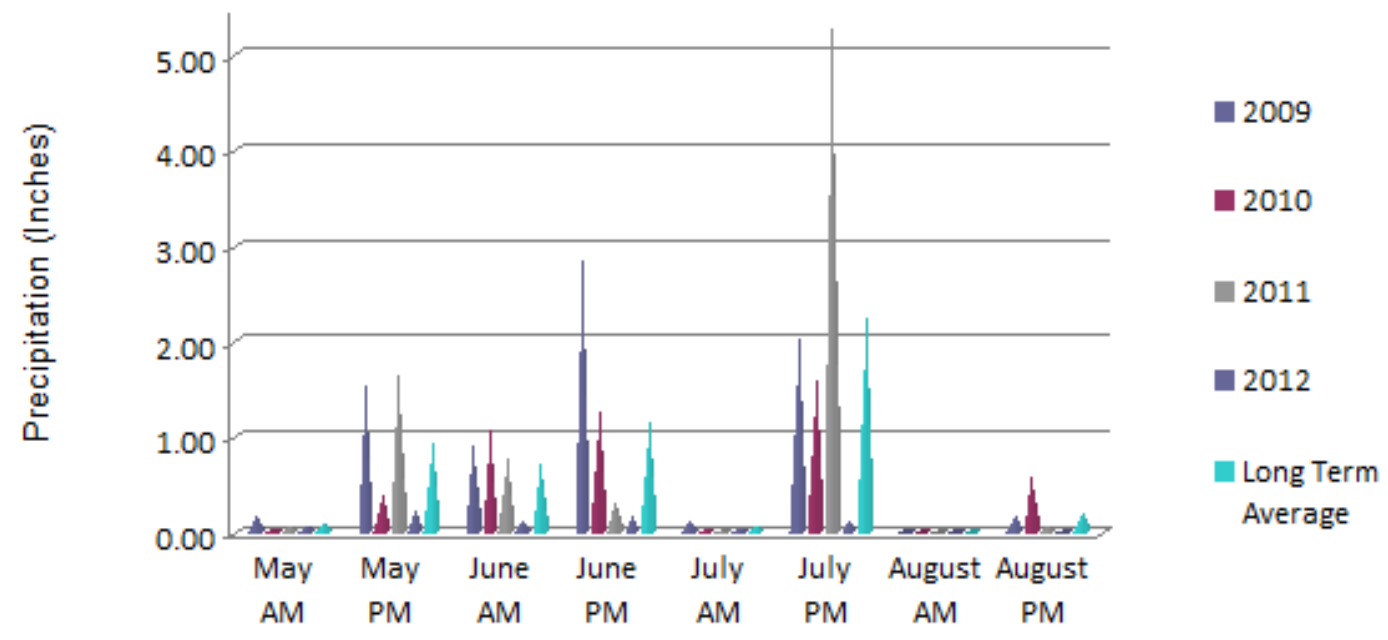

Figure 9. Analysis of NWTC precipitation data 2009 to 2012 with midnight to noon (a.m.) and noon to midnight (p.m.) data separated. 


\section{Interactions among Treatments}

In analyses above, ANOVA results were used to examine the overall effects of seed mix, cultural technique, or shading treatment. For example, when seed mix was examined above, the results of differing seed mix across all variations of cultural or shading treatments were combined (by the ANOVA process) and statistically tested for significant difference. ANOVA also allows statistical examination of smaller subsets of data to ascertain whether, for example, for individual cultural treatments the results of differing seed mix were the same or different from the overall result. A three-way ANOVA, as used here, results in very large numbers of combinations of treatments. Statistics for the full three-way interaction effects of 2012 cover data are presented in Appendix F. Interactions at the two-way levels are discussed below where they were of interest. 
Seed Mix vs. Cultural Treatment Interactions

Total Percent Vegetation Cover:

\section{Treatment}

$\begin{array}{lccc}\text { Seed Mix } & \text { A1 } & \text { A2 } & \text { A3 } \\ \text { P1 } & 97.1 & 92.5 & 84.8 \\ \text { P2 } & 53.4 & 65.7 & 66.5 \\ \text { P3 } & 75.6 & 75.1 & 80.0 \\ \text { P4 } & 72.8 & 73.0 & 78.7\end{array}$

Taken all together, the interaction difference was significant among the numbers above at the $\mathrm{P}=$ 0.01 level. From the matrix above it can be seen that by far the highest total vegetation cover was associated with seeding only the two warm-season grasses (seed mix P1, buffalograss and blue grama) in the absence of any cultural assistance (i.e., left bare, cultural treatment A1). For coolseason grasses (seed mix P2), the effect of the bare treatment was the opposite, resulting in the least total vegetation cover. When warm and cool were mixed (P3 and P4), the matting environment was apparently most favorable. Although soil temperature data were not collected, it is surmised that the bare cultural treatment had the highest soil temperatures, at least during the first year. This may have allowed the warm-season grasses to accomplish more underground development in the first year that subsequently lead to greater growth in 2011 and 2012.

When only the Percent Cover by Warm-Season Grasses is considered:

\section{Warm-Season Grasses}

\section{Treatment}

\begin{tabular}{lrrr} 
Seed Mix & \multicolumn{1}{c}{ A1 } & \multicolumn{1}{c}{ A2 } & \multicolumn{1}{c}{ A3 } \\
P1 & 69.9 & 71.2 & 63.4 \\
P2 & 3.9 & 0.8 & 0.6 \\
P3 & 53.8 & 43.7 & 44.3 \\
P4 & 33.2 & 40.6 & 37.9
\end{tabular}

There are some apparent and interesting differences in this matrix such as, for example, that warm-season grass growth (when in the mix with cool seasons, P3) was highest in the bare treatment but in the presence of cool-season grasses plus legumes (P4), warm-season grass growth was highest in the annual rye cultural treatment. However, they were not statistically significant. This demonstrates the value of ANOVA.

When only the Percent Cover by Cool-Season Grasses is considered:

\section{Cool-Season Grasses}

\section{Treatment}

$\begin{array}{lrrr}\text { Seed Mix } & \text { A1 } & \text { A2 } & \text { A3 } \\ \text { P1 } & 0.4 & 0.4 & 0.6 \\ \text { P2 } & 19.6 & 27.4 & 40.2 \\ \text { P3 } & 2.7 & 3.1 & 15.8 \\ \text { P4 } & 5.1 & 6.0 & 19.2\end{array}$


The matting treatment $(\mathrm{A} 3)$ significantly $(\mathrm{P}=0.001)$ enhanced the cover of the cool-season grasses when they were in the mix. This may relate to cool-season grass rooting depth. These cool-season grasses (Canada bluegrass and creeping red fescue) have comparatively shallow roots, and matting is likely to maintain adequate soil moisture in the upper soil for a longer period than bare ground by limiting evaporation. Blue grama and buffalograss possess deeper roots, and it would appear that the effects of the mat in conserving moisture may not extend to the deeper soil layers. Therefore, no significant differences between cultural treatments were observed for these warm-season grasses as of the third year of growth (2012).

\section{Seed Mix vs. Shading Interactions}

For total vegetation cover, warm-season grasses, weeds, all other volunteers, and native volunteers, no significant differences were observed in interaction effects of seed mix versus shading. However, for cool-season species, there were significant differences.

Percent Cover by Seed Mix and Shading Location:

\begin{tabular}{lrcc} 
& \multicolumn{3}{c}{ "Shading Treatment" } \\
Seed Mix & W & M & E \\
P1 & 0.4 & 0.4 & 0.7 \\
P2 & 16.0 & 28.4 & 42.8 \\
P3 & .6 & 6.24 & 10.8 \\
P4 & 4.6 & 6.6 & 19.1 \\
\hline
\end{tabular}

The significant differences at the $\mathrm{P}=0.001$ level were between $\mathrm{E}$ and $\mathrm{M}$ and $\mathrm{E}$ and $\mathrm{W}$ for the cool-season-only treatment. A difference significant at the $\mathrm{P}=0.01$ level was apparent for the $\mathrm{M}$ and W shading when only cool-season species had been planted (Mix P2).

For Mix P4 (warm- plus cool- season plus legumes), there was significant difference between $\mathrm{M}$ and $\mathrm{E}(\mathrm{P}=0.01$ level $)$ and between $\mathrm{W}$ and $\mathrm{E}(\mathrm{P}=0.001)$.

That the latter was not an effect of just the cool-season grass species is demonstrated by the fact that the cover of legumes only (below) was significantly different between $\mathrm{E}$ and $\mathrm{M}$ and between $\mathrm{E}$ and $\mathrm{W} \mathrm{P}=0.001$ ). In other words, both the cool-season grasses and legumes (also utilizing the cool-season or C3 pathway) were enhanced by the moisture supplement present in the East shading area.

Legume Percent Cover by Seed Mix and Shading Location:

\begin{tabular}{lccc} 
& \multicolumn{3}{c}{ "Shading Treatment" } \\
Seed Mix & W & M & E \\
P1 & 0.08 & 0.00 & 0.00 \\
P2 & 0.19 & 0.03 & 0.03 \\
P3 & 0.03 & 0.00 & 0.08 \\
P4 & 2.39 & 3.61 & 6.08 \\
\hline
\end{tabular}

\section{Cultural Treatment vs. Shading Interaction}

There were no significant interactions for the Cultural Treatment versus Shading variables. 


\section{Implications of This Work for Future PV Revegetation}

\section{Revegetation is Feasible}

Prior to initiating this study, and because of the paucity of information in the literature, it was not certain that revegetation beneath any PV arrays was possible or desirable. However, at the NWTC site, this test clearly indicates that revegetation is not only possible but can achieve ground cover sufficient to control erosion and to begin to restore wildlife habitat. Further, successful establishment of low-growing warm-season grasses also achieves the goal of retaining short vegetation to avoid interference with panels and minimize fuel load for potential wildfires. While these test results apply most directly to this particular panel configuration on a site with similar soil and weather conditions, the methods used in this study are applicable to other sites. This particular array is sufficiently open and the individual panels are small enough that the negative impacts of shading and rainfall interception are limited. Every case is different for reasons that may seem negligible; however, these reasons are often very important to revegetation success.

\section{Application of Study Results to Other Sites}

Each site on which revegetation of a PV array might be undertaken will offer different ecologically important attributes including elevation, aspect, soils, rainfall, land use history, wildlife use, fire susceptibility, etc. Thus the results from any particular study are project-specific and cannot be expected to apply universally. Nonetheless, methodologies and insights from the present study regarding project design, species selection, seeding applications, and cultural techniques can be applied to other projects. When evaluating the data from this study, however, it should be noted that different results would likely be seen, depending on whether the PV arrays are fixed or whether they track the sun. A key outcome of this effort that likely would be applicable in other locations was that there was no significant differences in vegetation performance resulting from the three different cultural treatments (bare soil, nurse crop, straw matting) after three years. Specific outcomes related to the performance of particular seed mixes and the effects of shading are likely to be site-specific.

\section{Soils Considerations}

The soils of the test plot area are limited in their production potential by rockiness, low organic matter, and heavy clay subsoil and are not suitable for crop production. In addition, topsoil was largely removed in site grading. The remaining subsoil materials, paradoxically, have high clay and coarse fragment $(>2 \mathrm{~mm})$ content. However, the materials are not strongly salt-affected and do have adequate nitrogen, phosphorous, and potassium for growth of native plants. (Were fertilizer to have been added, it is highly likely that weed growth would have been much more a problem with very little or no compensating advantage to the desired species.) In sum, soils limitations at this particular site were only moderate relative to difficulties for revegetation based on soil characteristics in many parts of the western United States. It is likely that solar arrays in future planned utility-scale projects would be placed in areas of the western United States with soils of negligible agricultural significance. In those cases, the soils beneath those arrays may pose challenges more severe than in the NWTC area. These issues could include salt content and, in particular, the dispersive effects of sodium, making it very difficult to establish seeded species. High salt content can affect the uptake of water by non-adapted plants and can also limit infiltration of incident moisture into the soil because dispersed clays seal the surface and limit the passage of water downward. If salt-affected soils are graded to prepare for collector 
construction, the chances for bringing up damaging salts from the subsoil layers would be high. Surface salt crusts on soils can also prevent erosion; certain construction activities without accompanying vegetation seeding could destroy the salt layer and make the soil more susceptible to erosion. The presence of vegetation can help reduce erosion as well as the spread of dust and other potential contaminants that could be present in soils. Development of utility-scale solar projects on former agricultural lands or soils that have high productivity could face different challenges associated with native and non-native volunteer species.

\section{Limitations to Plant Growth Beneath Solar Arrays}

The array at this test site is configured in a manner such that an average of about one-third of the ground is shaded during the day, and almost no portion of the ground beneath is devoid of direct sunlight (on a clear day). Shading, however, ranges from as little as about $20 \%$ to $25 \%$ at midday (Photograph 1) to as much as 50\% in early morning or later afternoon (Photograph 10). Many other designs, in particular fixed panel installations (for example, see Photograph 11), shade a much larger proportion of the ground surface. Inasmuch as interception of sunlight by solar collectors is at the heart of their design, the absence of direct sunlight beneath collectors is unavoidable. In some of these installations, only indirect light from around the edges will be available to plants on the ground. This could potentially be an advantage in arid regions, as some shading will benefit plants during peak sunlight hours and also provide hospitable conditions for shade-tolerant plants.

Likely more severely limiting than lack of light beneath panels is moisture unavailability. Except on sub-irrigated sites (a characteristic that would have almost certainly been eliminated by engineering considerations in site selection or by engineering remedial design) the only means for moisture to reach beneath the edges of panels is splash and subsurface soil wetting cone expansion. Thus, plant sustenance, in the form of direct water uptake by roots, is likely to be very difficult to impossible beyond a distance of perhaps 0.5 to $1 \mathrm{~m}$ from the collector edge. At some solar array installations, washing the collector surfaces to remove dust and other debris is anticipated. The moisture associated with this water as it runs off onto the ground will still concentrate near the panel edges. The collectors of the NREL NWTC test site are approximately $1 \mathrm{~m}$ wide. Vegetation inhibition / depression (likely the product of moisture deprivation) is qualitatively apparent beneath the center of these panels (Photograph 3 ). This effect was small enough that it was not noticeable in the test plot results. However, it shows that even a $1 \mathrm{~m}$-wide obstruction located $1 \mathrm{~m}$ above the ground can cause a noticeable reduction in plant growth approximately $0.5 \mathrm{~m}$ from the edge of the obstruction.

\section{Wildlife Considerations}

Although this test-plot study did not specifically address the degree to which successful revegetation was accompanied by reestablishment of wildlife use, incidental observations suggest that at least to some it extent it has. Deer bedding appeared to be common among the collectors, and use of the collectors as perches by birds was commonly observed. Lack of visibility due to the dense grouping of collectors might discourage use by some animals such as prairie dogs. For others, the physical complexity of the collectors could be expected to constitute safe haven from aerial predators. Certainly the plant species that succeeded in the plots are associated elsewhere with actively used wildlife habitat and could be equally expected to function in providing food and cover beneath the arrays. 


\section{Weed Considerations}

During the study, state-prohibited noxious weeds (Colorado B-list; no A-list species appeared) were periodically removed in conformance with legal requirements. The degree to which this removal of noxious species (almost entirely diffuse knapweed) materially enhanced the quantitative results reported here is not known, but it is likely a marginal effect, if any. Complete absence of weeds is not likely, but an invasion of weeds that displace desirable species is very unlikely based on patterns of restoration elsewhere in the Intermountain West. On future PV array sites where revegetation is undertaken, it is important to understand that the prevalence of annual or biennial opportunistic plants (i.e., weeds in the general sense) during the first year or two is natural. Weed control is something that may be needed on some sites and not on others. Not all weeds pose the threat to dominate and prevent establishment of the desired species. Some actually perform as nurses, sheltering and obscuring seedlings from physical and biological dangers. This underscores the importance of including involvement of ecologists familiar with regional restoration results in project planning and implementation.

\section{Impacts of Construction of Solar Arrays on the Ecology of Landscapes}

An important difference exists between development of solar energy-generating facilities and extracted energy such as coal. Coal extraction in its most well-known form-surface miningcan be massively disruptive to landscapes. This was recognized in the 1977 federal Surface Mine Control and Reclamation Act (SMCRA). As a result of this law, the enterprise of coal removal was required to comprise no more than a temporary land use in most cases. During and following coal removal, the potential for reconstruction of previously extant land uses and productivity must be maintained in, for example, the salvage and redistribution of carefully segregated topsoil resources. Following completion of coal removal, landscapes are reconstructed (in the western United States) and very explicit and quantitative performance standards are applied to judge the adequacy of revegetation after a 10 -year waiting period. While solar development is not nearly as destructive to landscapes as other energy extraction activities, the degree to which a solar array is a temporary land use is unclear. Although the solar array has a limited lifespan, in many areas there are no laws or regulations governing post-project landscape restoration as currently required by law for coal extraction.

Utility-scale solar development that employs conventional site preparation techniques (e.g., grading, razing, etc.) to satisfy engineering requirements can be destructive to the often fragile life that soil comprises. Whether considering only the potential to support growth of vascular plants or, more appropriately, the totality of soil organisms (fungi, bacteria, and invertebrate animals, many of which are yet to be known), scraping of soils to prepare sites for utility-scale solar arrays in arid zones can have a large environmental impact. Developing methods for revegetating areas beneath solar arrays, as well as installing the arrays without grading, could help mitigate environmental impacts on multiple landscape scales. 


\section{Summary}

This effort evaluated the performance of vegetation under a solar energy installation by incorporating multiple seed mixes, cultural treatments, and shade effects. Given the particular physical characteristics of the NWTC array and the objectives of various stakeholders, this study showed that short-growing, warm-season grasses, with or without cool-season, shade-tolerant species or legumes, could produce an extensive plant cover within a 3-year period. Warm-season short grasses sown on bare ground produced the highest cover percentage (via high cover by the warm-season grass and volunteer forbs), but the combination of cool-season grass and legumes also produced high cover percentages. Establishment of cool-season grasses was highest when straw matting was used.

The NWTC PV array, beneath which the revegetation test-plot studies reported here were conducted, is a tracking array with rows of collector panels running north to south, the panels daily following the sun east to west. The panels are mounted approximately $1 \mathrm{~m}$ above the ground with approximately $1.5 \mathrm{~m}$ space between when level (noon). The tracking movement allows more sunlight to reach the ground than would most fixed panel arrays (e.g., Photograph 11) because they typically are oriented in east to west rows and are spaced to maximize interception of direct sunlight. However, they are mounted comparatively close to the ground, which could restrict light access. Overall, however, conditions for plant growth in this test-plot study are likely better than would be the case for arrays in which large fixed panels were present. Likewise, the environment of NWTC is characterized in most years by the presence of late spring and early summer thunderstorms that during this study supported good germination and establishment of the seeded plants in certain portions of the test plots. This array was not fenced. Were the array to have been fenced, wildlife access would have been more limited. In PV installations where fencing is used, gates, fencing modifications, and other openings can be used to allow wildlife access (see e.g., Brookhaven National Laboratory 2011). The installer, however, may need to protect wiring by placing it in conduit.

In the future, design of revegetation approaches for PV arrays will need to consider both panel design/configuration and local climate in selecting species and cultural methods. The degree to which physical destruction of soils and pre-existing vegetation during clearing and grubbing and grading operations can be avoided by creative and pragmatic construction design will have a large effect on the prospects of successful revegetation at most sites. All revegetation is local, and full analysis and consideration of local conditions of soils and climate as well as constraints of the physical array design will be needed for each site. This study provides the methodological foundations upon which future revegetation efforts can build to better understand how different types of vegetation perform under solar installations based on their region-specific conditions and solar installation configuration. 


\section{Citations}

1. Althouse and Meade, Inc. 2011. "Habitat Restoration and Revegetation - Topaz Solar Farm."

2. Armstrong, A., J.O. Nicholas, W. Jeanette. 2016. Solar Park Microclimate and Vegetation Management Effects on Grassland Carbon Cycling. Environmental Research Letters 2016, 11, (7), 074016.

3. Armstrong, A., S. Waldron, J. Whitaker, and N. J. Ostle. 2014. "Wind Farm and Solar Park Effects on Plant-soil Carbon Cycling: Uncertain Impacts of Changes in Groundlevel Microclimate.” Global Change Biology 20 (6): 1699-1706.

4. Arsenault, J. (2010). Proposed Solar Panel Vegetation Impacts: Stafford Landfill Solar Installation: Structure and Shading Impacts. Web posting site: http://www.pinelandsalliance.org/downloads/pinelandsalliance_512.pd . Report prepared July 2010.

5. Barbose, G. 2013. "An Historical Summary of the Installed Cost of Photovoltaics in the United States from 1998 to 2012." Lawrence Berkely National Laboratory.

6. Birkeland, P. W., D. C. Miller, P. E. Patterson, A. B. Price, and R. R. Shroba. (1996). Soil-geomorphic relationships near Rocky Flats, Boulder and Golden, with a stop at the pre-Fountain Formation paleosol of Wahlstrom (1948). Colo. Geol. Surv., Special Publ.(CD-ROM) 44. 13 pp.

7. Bönigk, N., and B. Dannemann. 2010. "Solar park-Opportunities for Biodiversity: A Report on Biodiversity in and around Ground-Mounted Photovoltaic Plants."

8. $\quad$ BRE (Building Research Establishment). 2013. "Planning Guidance for the Development of Large Scale Ground Mounted Solar PV Systems.” BRE National Solar Centre. London. Available at: https://www.bre.co.uk/filelibrary/pdf/other_pdfs/kn5524_planning guidance reduced. pdf

9. Brehaut, C. 2015. "Megawatt-Scale PV O\&M and Asset Management 2015-2020." Greentech Media Inc.

10. Brookhaven National Laboratory (2011). http://www.bnl.gov/GARS/SET/LISF.php. Accessed on May 18, 2013.

11. Buckner, D. Unpublished Data.

12. Burney, J., L. Woltering, M. Burke, R. Naylor, and D. Pasternak. 2010. "SolarPowered Drip Irrigation Enhances Food Security in the Sudano-Sahel." Proceedings of the National Academy of Sciences 107 (5): 1848-53.

13. Cameron, D. R, B. S. Cohen, and S. A. Morrison. 2012. "An Approach to Enhance the Conservation-Compatibility of Solar Energy Development." PloS One 7 (6): e38437.

14. Cook, L. M., and R. H. McCuen. 2013. "Hydrologic Response of Solar Farms." Journal of Hydrologic Engineering 18 (5): 536-41.

15. Copeland, H. E., A. Pocewicz, and J. M. Kiesecker. 2011. “Geography of Energy Development in Western North America: Potential Impacts on Terrestrial Ecosystems." In Energy Development and Wildlife Conservation in Western North America, 7-22. Springer. 
16. Dabney, S. M., M. T. Moore, and M. A. Locke. 2006. "Integrated Management of inField, Edge-of-Field, and after-Field Buffers." Journal of the American Water Resources Association 42 (1): 15.

17. Dairy Farm Energy Efficiency | ATTRA | National Sustainable Agriculture Information Service.” 2016. Accessed March 4. https://attra.ncat.org/attrapub/viewhtml.php?id=198.

18. Dairyland Power Cooperative. 2016. "Dairyland Power Announces Makor Solar Projects."

19. Department of Energy (DOE) (2012). Final Programmatic Environmental Impact Statement (PEIS) for Solar Development in Six Southwestern States. FES 12-24 DOE/EIS-0403. July. http://solareis.anl.gov/documents/fpeis/Solar_FPEIS_Volume_1.pdf. Accessed on February 28, 2013.

20. Dupraz, C., G. Talbot, H. Marrou, J. Wery, S. Roux, F. Iiagre, Y. Ferard, and A. Nogier. 2011. "To Mix or Not to Mix: Evidences for the Unexpected High Productivity of New Agrivoltaic and Agroforestry Systems."

21. Dupraz, C., H. Marrou, G. Talbot, L. Dufour, A. Nogier, and Y. Ferard. 2011. "Combining Solar Photovoltaic Panels and Food Crops for Optimising Land Use: Towards New Agrivoltaic Schemes." Renewable Energy 36 (10): 2725-32.

22. EIA (Energy Information Administration),2016, Short-Term Energy Outlook, Available at http://www.eia.gov/forecasts/steo/report/. Accessed January.

23. EIA. 2013. "Updated Capital Cost Estimates for Utility Scale Electricity Generating Plants."

24. Energy Efficiency and Renewable Energy Clearinghouse (EREC). 2002. "Agricultural Applications of Solar Energy.” U.S. Department of Energy (DOE). February. http://infohouse.p2ric.org/ref/24/23989.htm.

25. EREC Brief: Agricultural Applications of Solar Energy.” 2016. Accessed March 4. http://infohouse.p2ric.org/ref/24/23989.htm.

26. ESCO Associates Inc. 2013. "National Wind Technology (NWTC) SunEdison 1 Megawatt PV Array Vegetation Test Plots Final Report."

27. Escobar, J. C., E. S. Lora, O. J. Venturini, E. E. Yáñez, E. F. Castillo, and O. Almazan. 2009. "Biofuels: Environment, Technology and Food Security." Renewable and Sustainable Energy Reviews 13 (6): 1275-87.

28. Fehr, R. L., and R. L. Huhnke. 1990. "Energy Conservation in Ventilating and Heating Swine Buildings."

29. Feldman, D., D. Boff, and R. Margolis. 2015. "Q2/Q3 2015 Solar Industry Update.”

30. First Solar. 2016. "Procurement \& Construction Management." http://www.firstsolar.com/en/Technologies-and-Capabilities/Procurement-andConstruction-Management.aspx.

31. Friedman, B., K. Ardani, D. Feldman, R. Citron, R. Margolis, and J. Zuboy. 2013. "Benchmarking Non-Hardware Balance-of-System (Soft) Costs for US Photovoltaic Systems Using a Bottom-Up Approach and Installer Survey - Second Edition." 
32. Goetzberger, A., and A. Zastrow. 1982. "On the Coexistence of Solar-Energy Conversion and Plant Cultivation.” International Journal of Solar Energy 1 (1): 5569.

33. Goodrich, A., T. James, and M. Woodhouse. 2012. "Residential, Commercial, and Utilityscale Photovoltaic (PV) System Prices in the United States: Current Drivers and Cost-Reduction Opportunities.” National Renewable Energy Laboratory (NREL).

34. GTM Research. 2014. "Ensuring Success in Global Utility Solar PV Projects." Greentech Media Inc.

35. Hartmann, H. M., M. A. Grippo, G. A. Heath, J. Macknick, K. P. Smith, R. G. Sullivan, L. J. Walston, and K. L. Wescott, 2016. Understanding Emerging Impacts and Requirements Related to Utility-Scale Solar Development, ANL/EVS-16/9. Argonne National Laboratory, Argonne, Illinois. September.

36. Hernandez, R. R., M. K. Hoffacker, and C. B. Field. 2014. "Land-Use Efficiency of Big Solar." Environmental Science \& Technology 48 (2): 1315-23.

37. Hernandez, R. R., M. K. Hoffacker, and C. B. Field. 2015. "Efficient Use of Land to Meet Sustainable Energy Needs." Nature Climate Change.

38. Hernandez, R. R., M. K. Hoffacker, M. L. Murphy-Mariscal, G. C. Wu, and M. F. Allen. 2015. "Solar Energy Development Impacts on Land Cover Change and Protected Areas." Proceedings of the National Academy of Sciences 112 (44): 13579 84.

39. Hernandez, R. R., S. B. Easter, M. L. Murphy-Mariscal, F. T. Maestre, M. Tavassoli, E. B. Allen, C. W. Barrows, J. Belnap, R. Ochoa-Hueso, and S. Ravi. 2014. "Environmental Impacts of Utility-Scale Solar Energy." Renewable and Sustainable Energy Reviews 29: 766-79.

40. Huff, J. 2013. "Solar Farms Grounds Management Vegetation Control.” Abakus Solar Blog. http://www.abakus-solar.us/blog/solar-farm-pv-power-plant-groundsmanagement-vegetation-control/.

41. Keating, T. J., K. Ardani, and A. Walker. 2015. "SAPC Best Practices in PV Operations and Maintenance." National Renewable Energy Laboratory (NREL).

42. Lovich, J. E., and J. R. Ennen. 2011. "Wildlife Conservation and Solar Energy Development in the Desert Southwest, United States.” BioScience 61 (12): 982-92.

43. Macknick, J., B. Beatty, and G. Hill. 2013. Overview of Opportunities for CoLocation of Solar Energy Technologies and Vegetation. NREL/TO-6A20-60240, National Renewable Energy Laboratory, Golden.

44. Malde, H. (1955). Surficial geology of the Louisville Quadrangle, Colorado. U.S.G.S. Bulletin 996E: 217-257.

45. Marrou, H., L. Guilioni, L. Dufour, C. Dupraz, and J. Wery. 2013. "Microclimate under Agrivoltaic Systems: Is Crop Growth Rate Affected in the Partial Shade of Solar Panels?" Agricultural and Forest Meteorology 177: 117-32.

46. Marrou, H., J. Wéry, L. Dufour, and C. Dupraz. 2013. "Productivity and Radiation Use Efficiency of Lettuces Grown in the Partial Shade of Photovoltaic Panels." European Journal of Agronomy 44: 54-66.

47. McDonald, R. I., J. Fargione, J. Kiesecker, W. M. Miller, and J. Powell. 2009a. "Energy Sprawl or Energy Efficiency: Climate Policy Impacts on Natural Habitat for the United States of America." PLoS One 4 (8): e6802. 
48. McDonald, R. I., J. Fargione, J. Kiesecker, W. M. Miller, and J. Powell. 2009b. "Energy Sprawl or Energy Efficiency: Climate Policy Impacts on Natural Habitat for the United States of America." PLoS One 4 (8): e6802.

49. McPheeeters, G. and T. Vaughn. 2011. accessed on May 6, 2016 at: http://www.homepower.com/articles/solar-electricity/design-installation/pv-groundmounting

50. MWPS-23. 1983. "Solar Livestock Housing Handbook.” Midwest Plan Service.

51. Northrup, J. M., and G. Wittemyer. 2013. "Characterizing the Impacts of Emerging Energy Development on Wildlife, with an Eye towards Mitigation.” Ecology Letters $16(1): 112-25$.

52. $\quad$ NREL. 2015. "Annual Technology Baseline and Standard Scenarios." http://www.nrel.gov/analysis/data_tech_baseline.html.

53. Ong, S., et al., 2013, Land-Use Requirements for Solar Power Plants in the United States, NREL/TP-6A20-56290, June. National Renewable Energy Laboratory, Golden, Colo.

54. Parker, G. 2014. "BRE National Solar Centre Biodiversity Guidance for Solar Developments." BRE National Solar Centre. London.

55. Pressman, A. 2010. "Dairy Farm Energy Efficiency | ATTRA | National Sustainable Agriculture Information Service.” ATTRA Sustainable Agriculture. https://attra.ncat.org/attra-pub/viewhtml.php?id=198.

56. R Development Core Team (2010). R: A language and environment for statistical computing. R Foundation for Statistical Computing, Vienna, Austria. ISBN 3-90005107-0, URL http://www.R-project.org/.

57. R Development Core Team 2010

58. Ravi, S., J. Macknick, D. B. Lobell, C. B. Field, K. Ganesan, R. Jain, M. Elchinger, and B. Stoltenberg. 2014. "Co-Location Opportunities for Renewable Energy and Agriculture in Northwestern India: Tradeoffs and Synergies." In , 1:07.

59. $\quad$ RSPB. 2014. “Advice for Farmers: Solar Farms.” November 26. http://www.rspb.org.uk/forprofessionals/farming/advice/details.aspx?id=367959.

60. Sage, R. F. and R. K. Monson. (1999). C4 Plant Biology. Academic Press, San Diego.

61. Scott, C. (2013). Solar Continued Exponential Growth in 2012, but Politics may Stymie Growth. Published by Singularity University. URL http://singularityhub.com/2013/08/18/solar-continued-exponential-growth-in-2012but-politics-may-stymie-growth/. Accessed on September 20, 2013.

62. Scurlock, J. 2014. "Agricultural Good Practices for Solar Farms.” BRE National Solar Centre. London Semchenko, M., M. Lepik, L. Götzenberger, and K. Zobel. 2012. "Positive Effect of Shade on Plant Growth: Amelioration of Stress or Active Regulation of Growth Rate?" Journal of Ecology 100 (2): 459-66.

63. Shiao, M. J. 2015. "PV Balance of Systems 2015: Technology Trends and Markets in the U.S. and Abroad." Greentech Media Inc.

64. Sokal, R. R. and J. Rohlf. 1969. Biometry. W. H. Freeman and Company., San Francisco. and/ or Snedecor, G. W. and W. G. Cochran. 1980. Statistical Methods, Seventh Edition. The Iowa University Press, Ames, IA. 
65. Stoms, D. M., S. L. Dashiell, and F. W. Davis. 2013. "Siting Solar Energy Development to Minimize Biological Impacts." Renewable Energy 57: 289-98.

66. Svejkovsky, C. 2006. "Renewable Energy Opportunities on the Farm.” ATTRA Publication.

67. Thompson, P., and M. G. Clary. 1978. Solar Heating for Milking Parlors. Dept. of Agriculture, Science and Education Administration: for sale by the Supt. of Docs., US Govt. Print. Off.

68. Turney, D., and V. Fthenakis. 2011. "Environmental Impacts from the Installation and Operation of Large-Scale Solar Power Plants.” Renewable and Sustainable Energy Reviews 15 (6): 3261-70.

69. USDA. 2011. "On-Farm Renewable Energy Production (2009).”

70. Weaver, J. E. 1919. The Ecological Relations of Roots. Carnegie Institution of Washington, Washington, D.C.

71. Xiarchos, I. M., and B. Vick. 2011. Solar Energy Use in US Agriculture: Overview and Policy Issues. US Department of Agriculture, Office of the Chief Economist, Office of Energy Policy and New Uses. 


\section{Appendix A}

\section{Photographs}

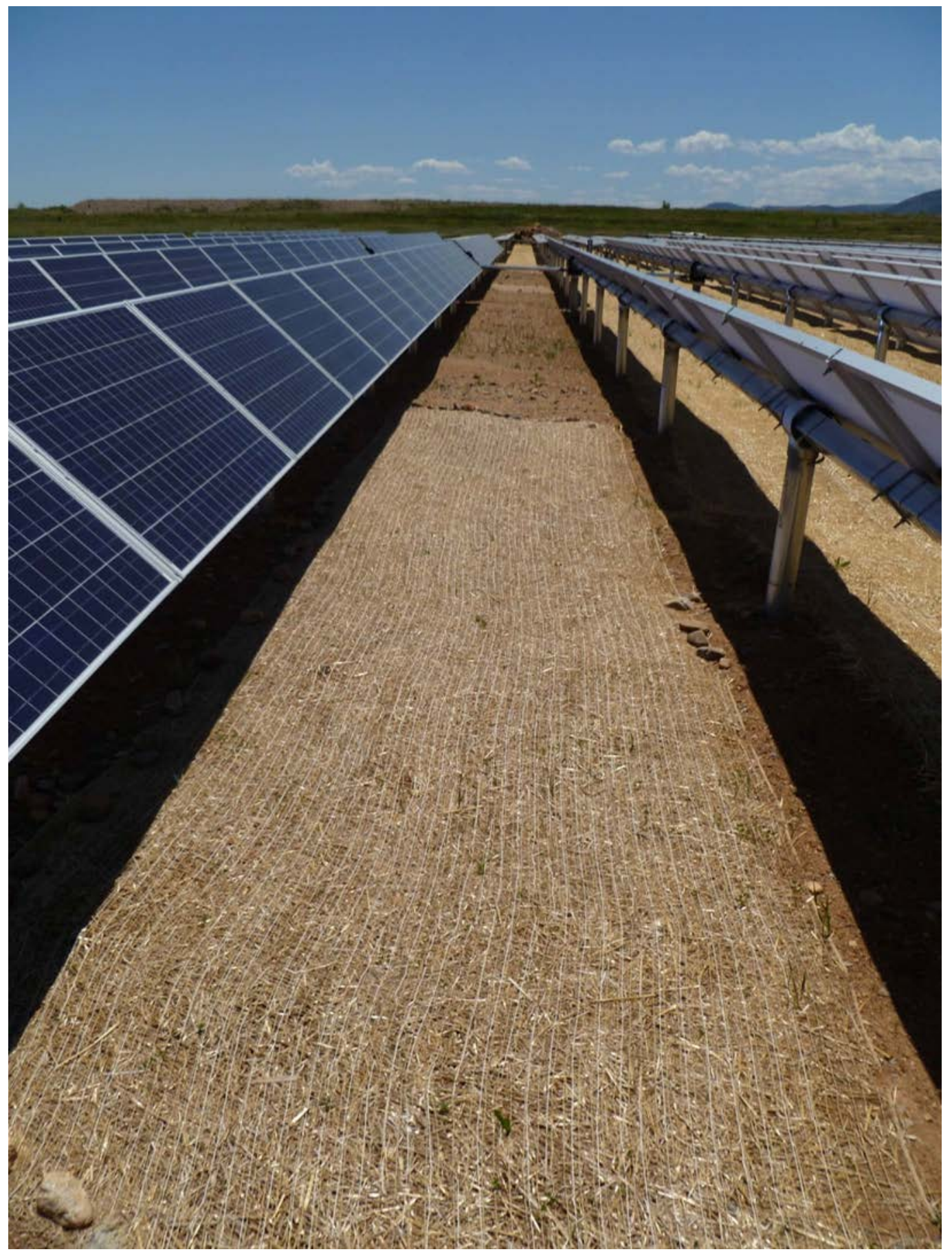

Photograph 1. View of test plots directed south during June 2010. Matting treatment (A3) shown in foreground. Photo Credit: Dave Buckner 


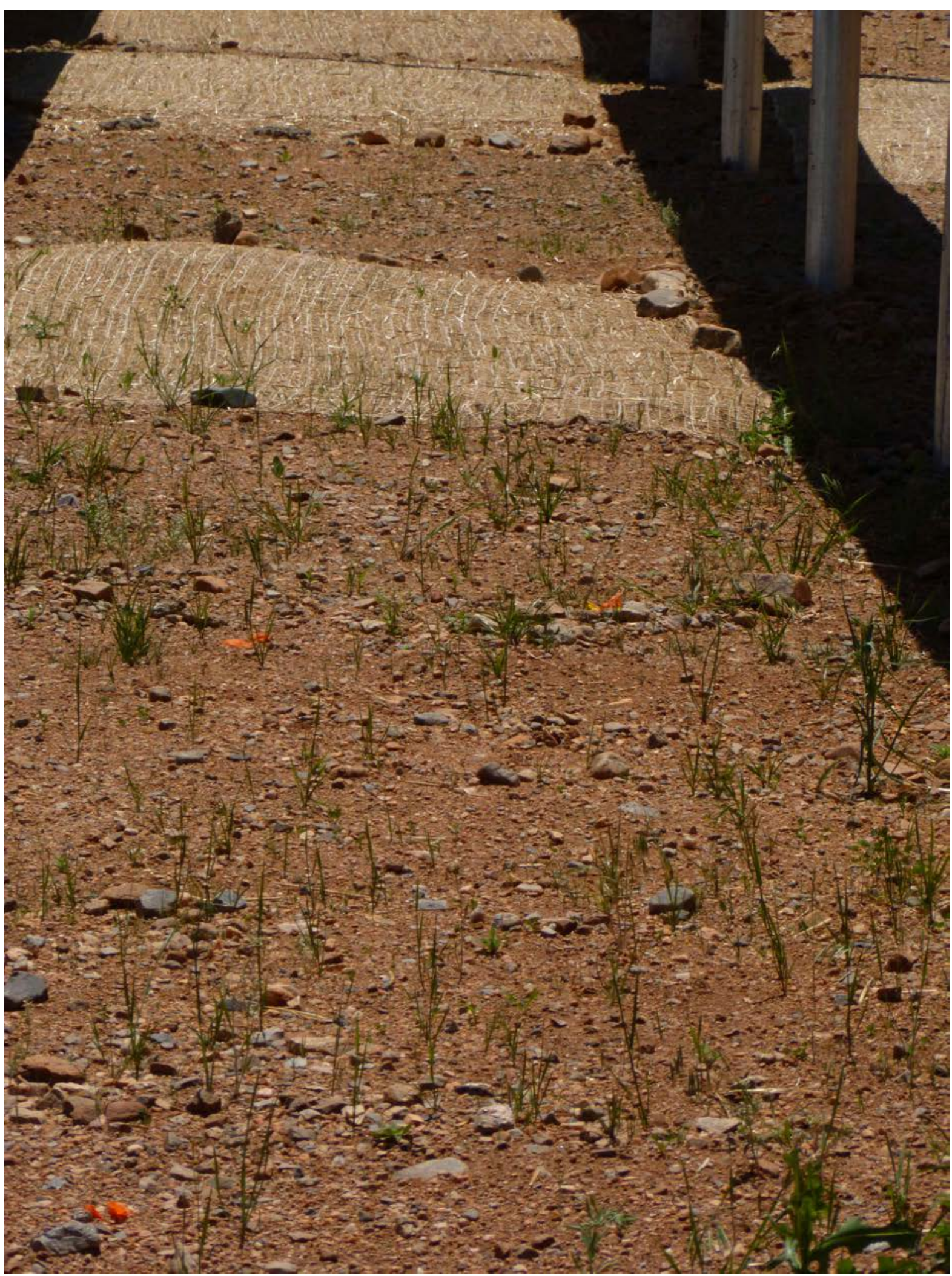

Photograph 2. Test Plots in June 2010. Foreground showing annual rye (Lolium multiflorum) nurse crop (A2); Midground showing matting treatment (A3); Background showing bare treatment (A1). Photo Credit: Dave Buckner 


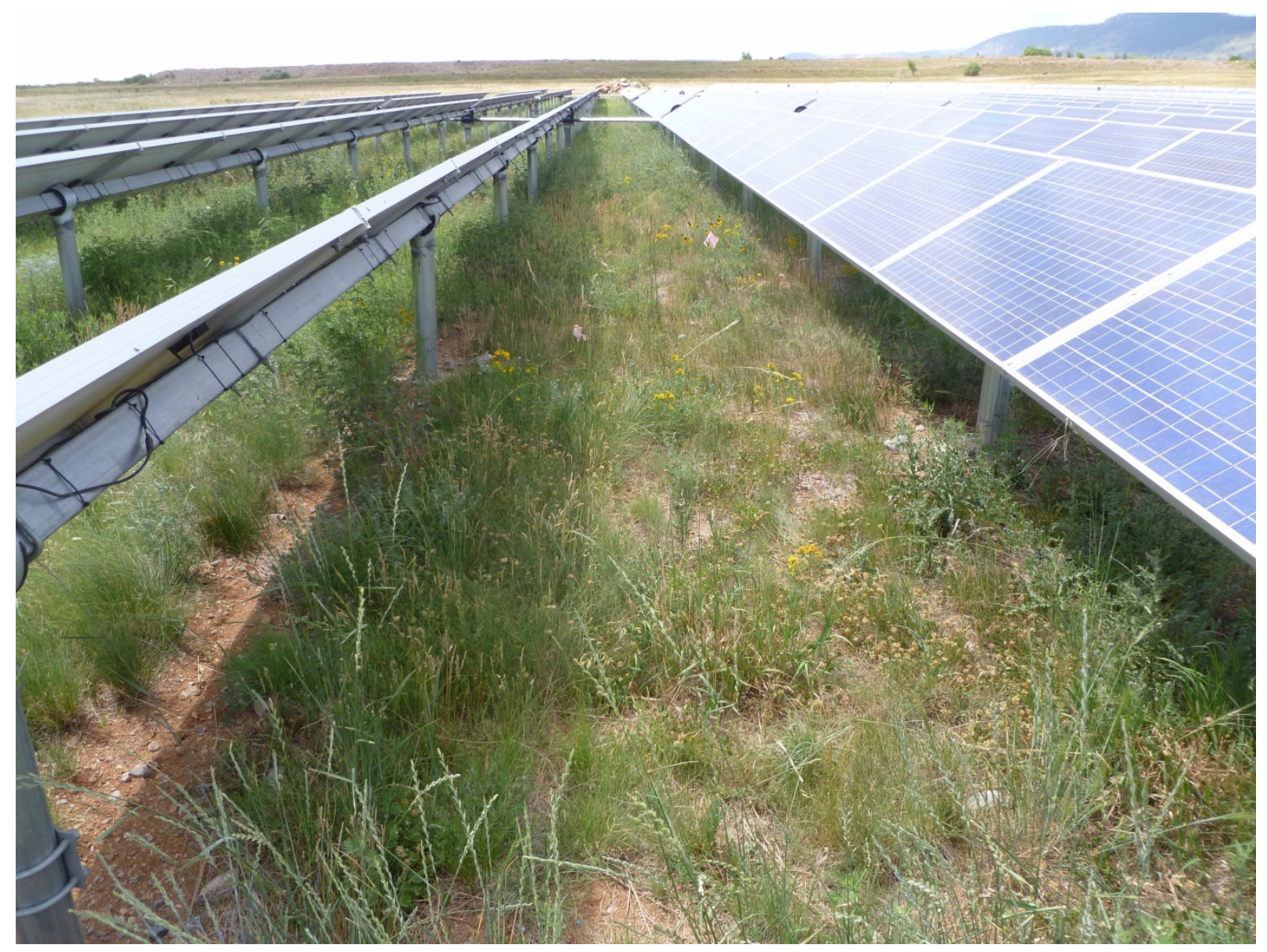

Photograph 3. Test Plots as of third year of growth (June 2012). Note extensive cover of grasses and paucity of cover directly beneath the panels. View faces south. Photo Credit: Dave Buckner 


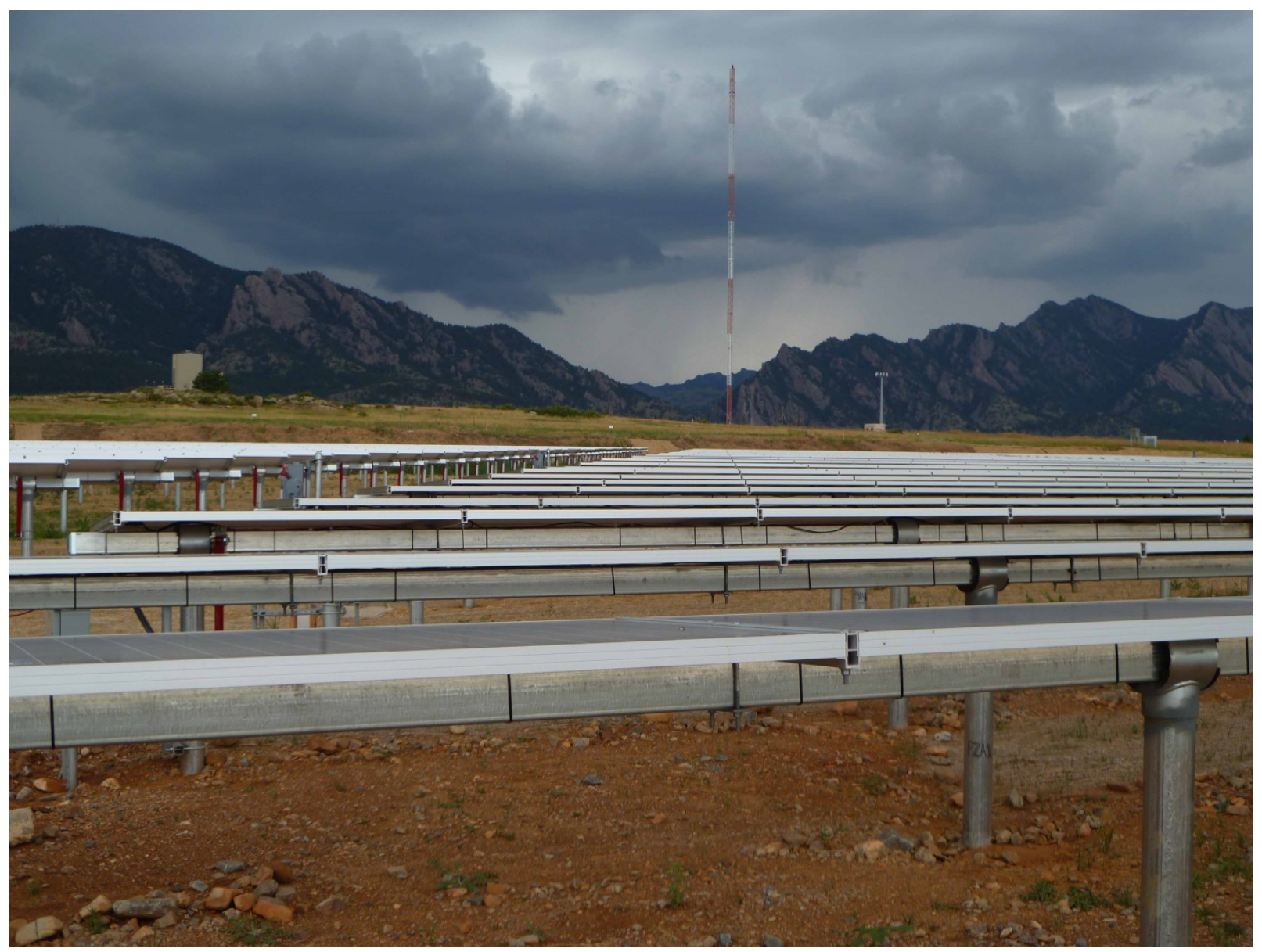

Photograph 4. Example of thunderstorm developing in late afternoon (as often is the case in late spring and summer - July 29, 2010). View faces west. Photo Credit: Dave Buckner 


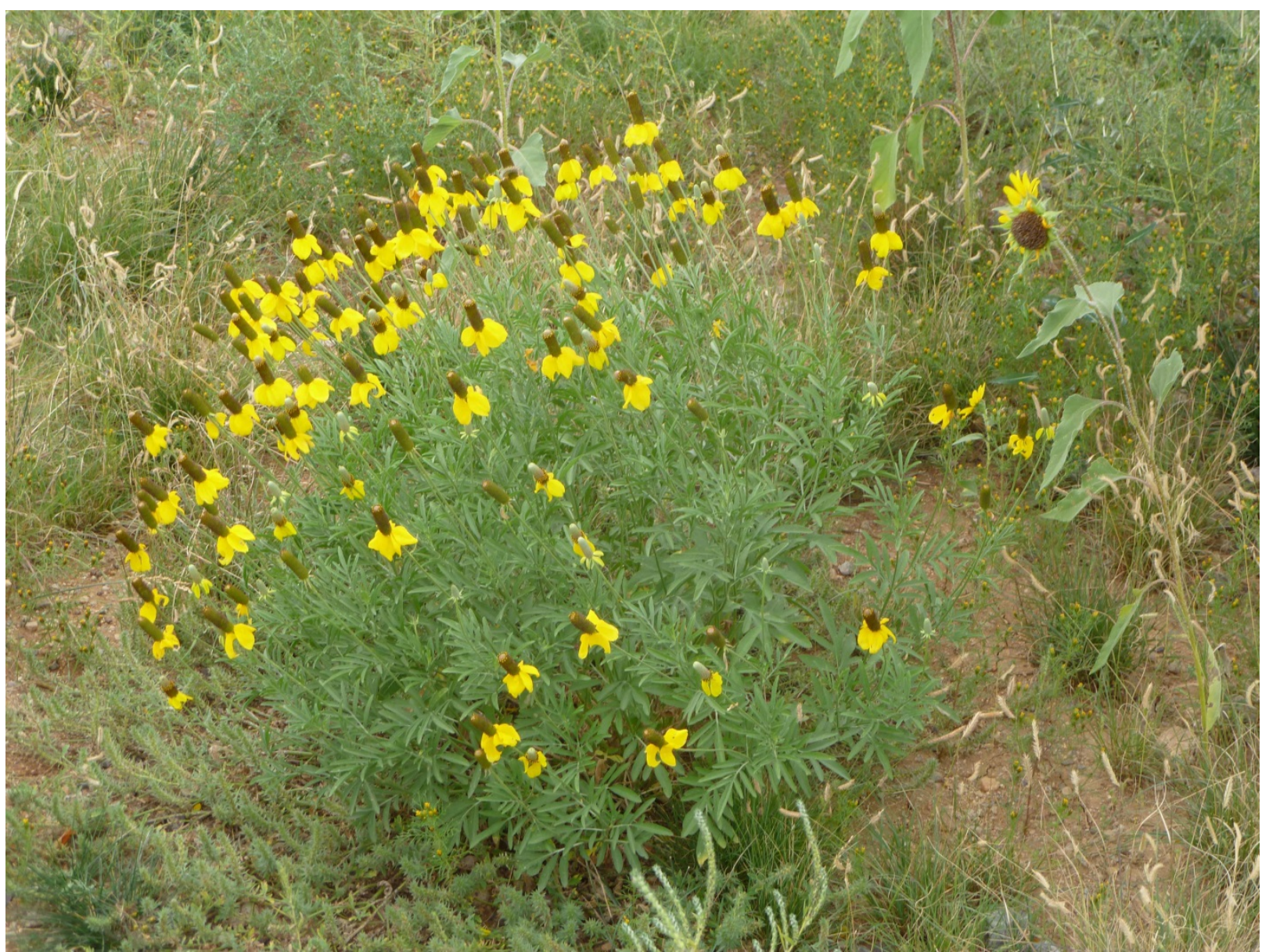

Photograph 5. Native prairie forbs and subshrubs that were not seeded found their way onto the site and germinated (prairie coneflower, Ratibida columnifera). Photo Credit: Dave Buckner 


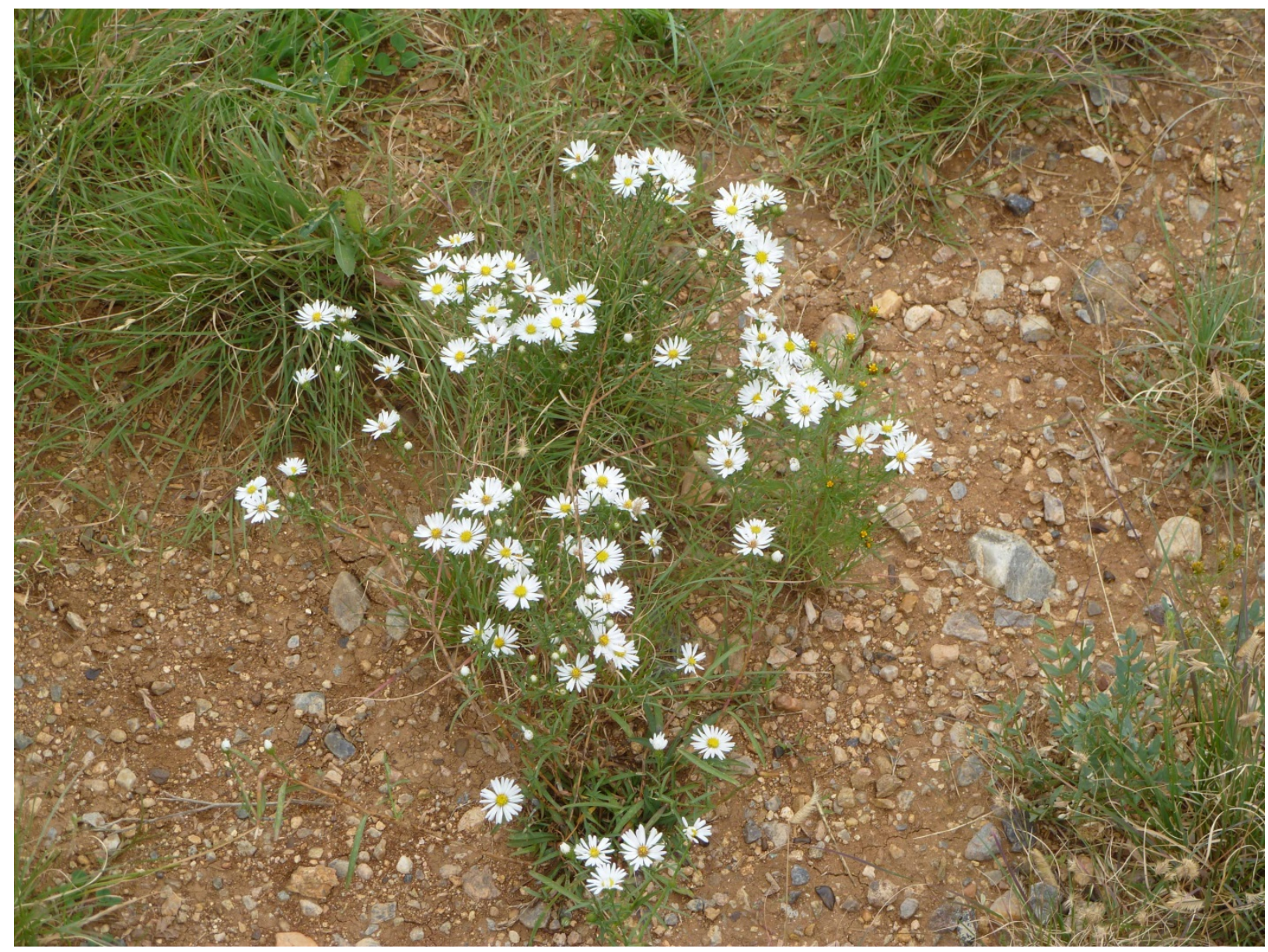

Photograph 6. Native prairie forbs and subshrubs that were not seeded found their way onto the site and germinated (Porter's aster, Aster porteri). Photo Credit: Dave Buckner 


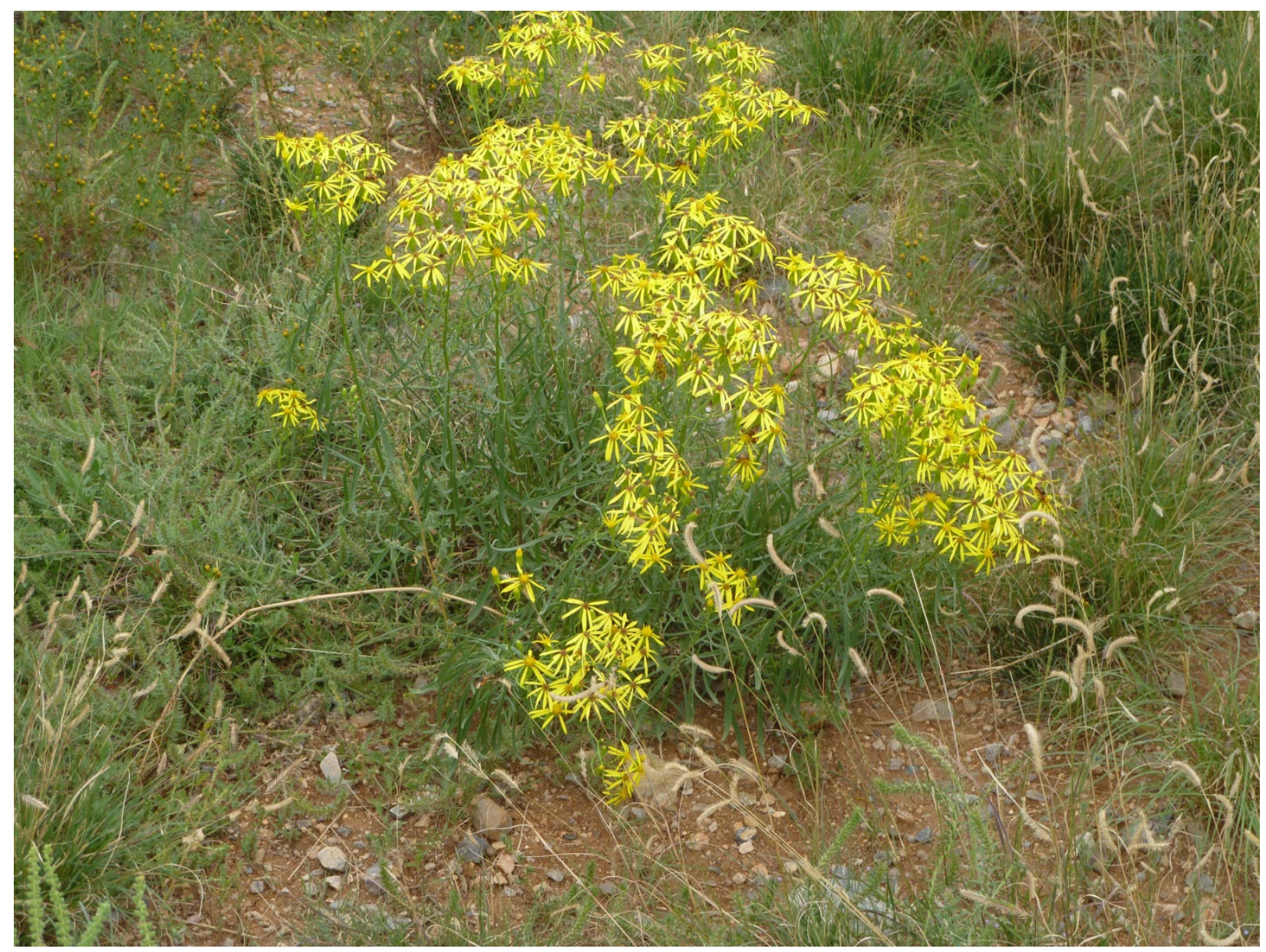

Photograph 7. Native prairie forbs and subshrubs that were not seeded found their way onto the site and germinated (Riddell's groundsel, Senecio spartioides). Photo Credit: Dave Buckner 


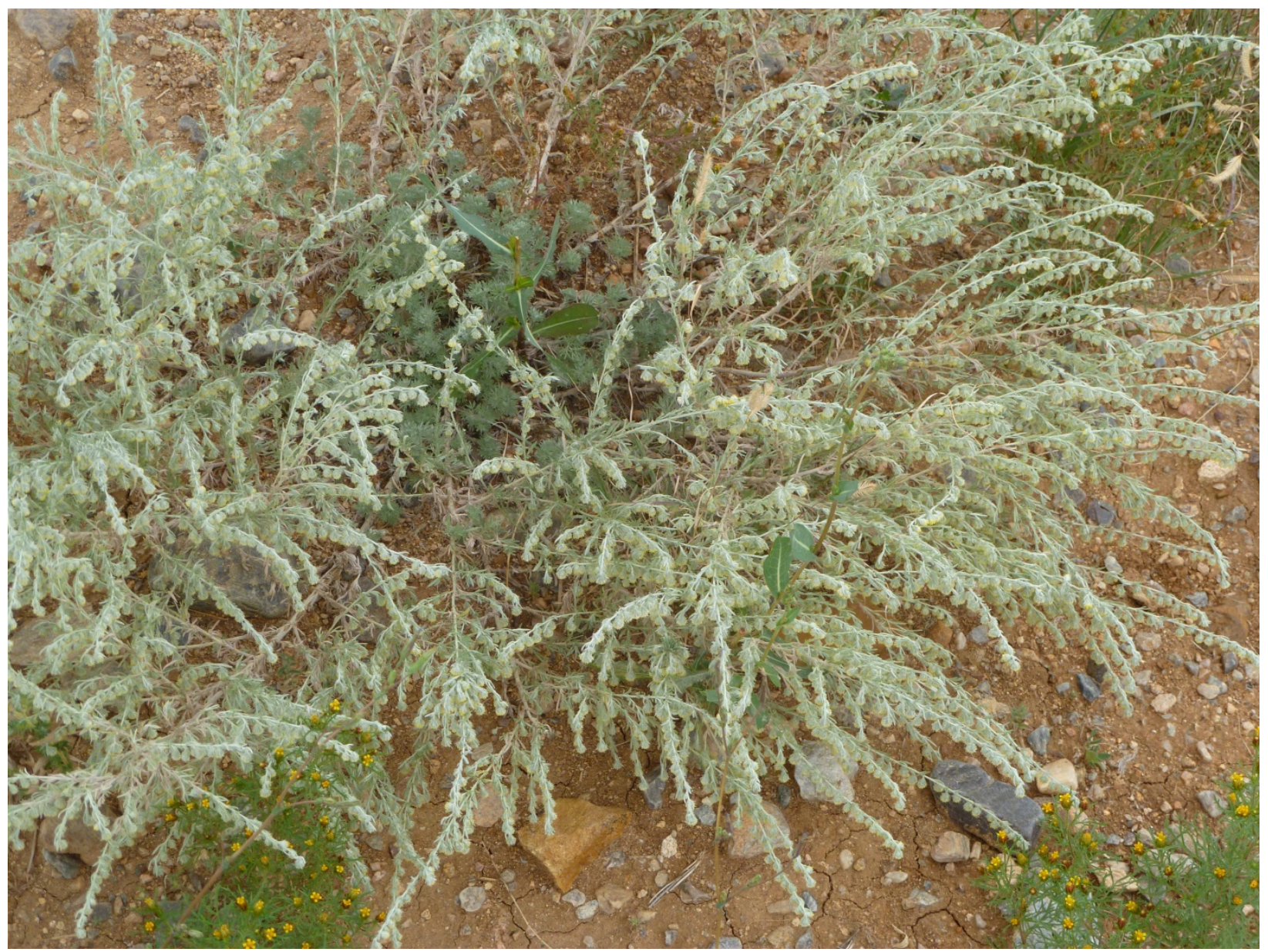

Photograph 8. Native prairie forbs and subshrubs that were not seeded found their way onto the site and germinated (fringed sagewort, Artemisia frigida). Photo Credit: Dave Buckner 


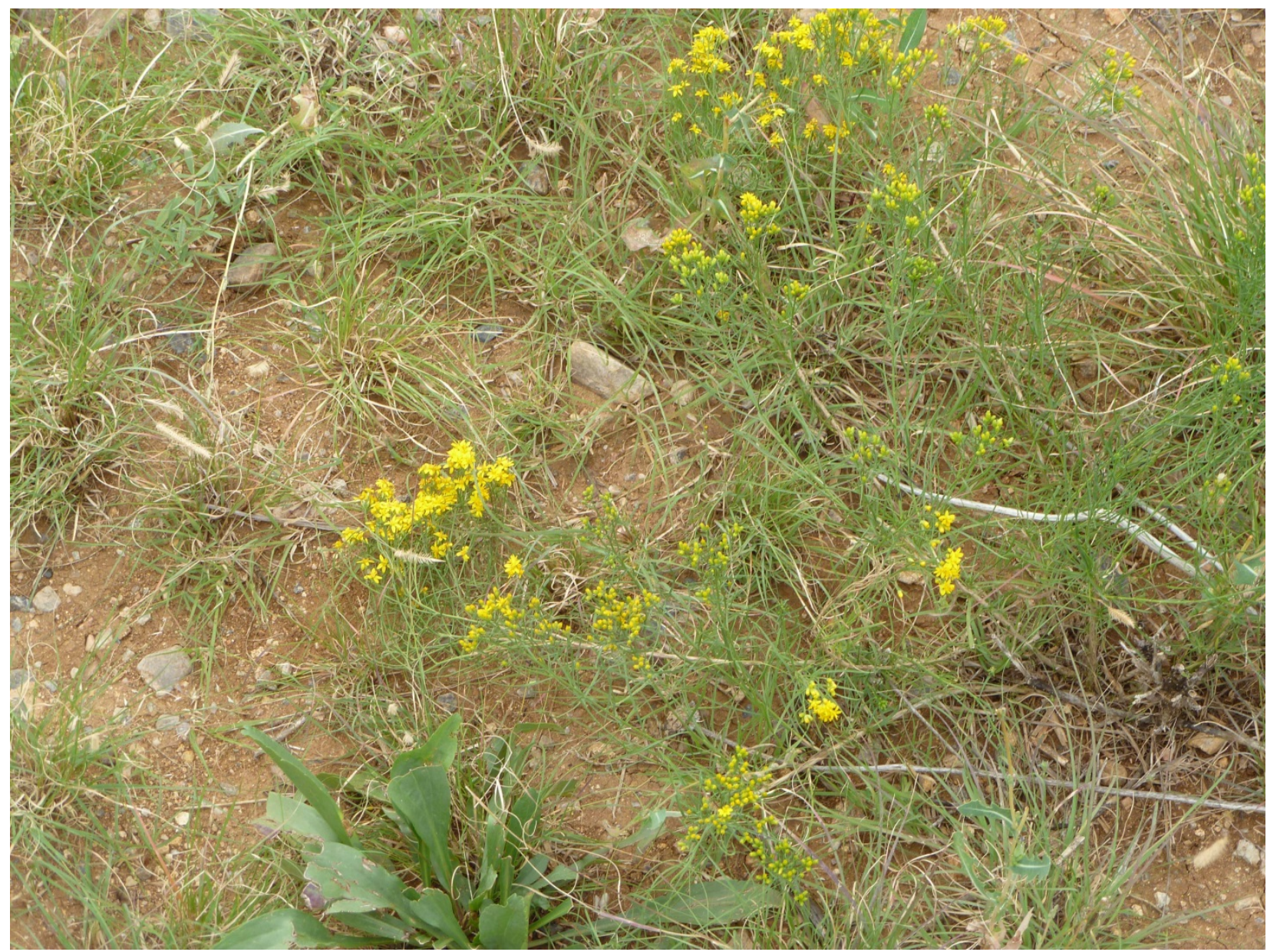

Photograph 9. Native prairie forbs and subshrubs that were not seeded found their way onto the site and germinated (snakeweed, Gutierrezia sarothrae). Photo Credit: Dave Buckner 


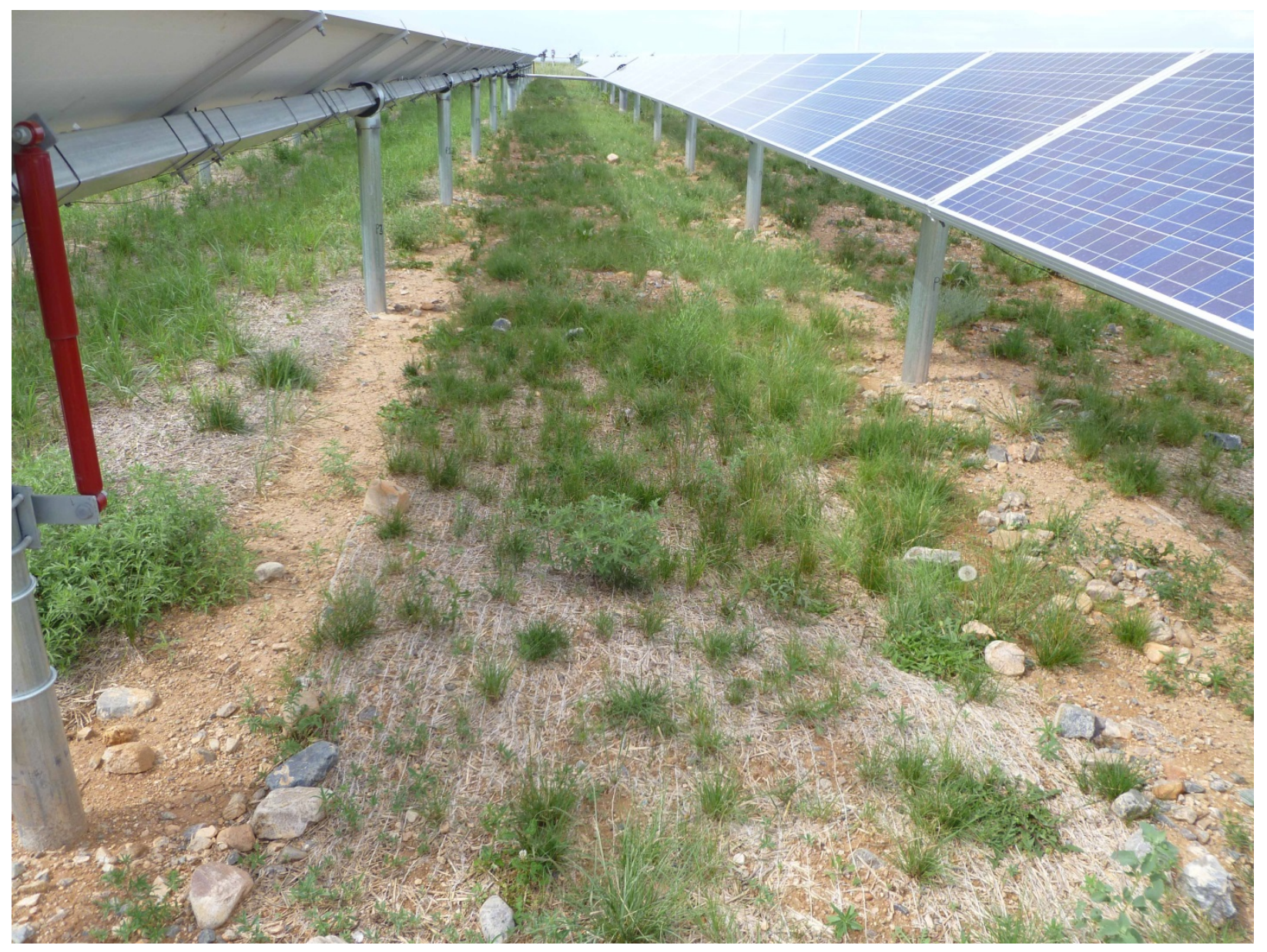

Photograph 10. NWTC tracker arrays arranged in N-S rows that allow sun to reach the ground. Shading from ca. $1 / 4$ to slightly more than $1 / 2$ ground surface. The shaded area varies throughout the day. View faces south. Photo Credit: Dave Buckner 


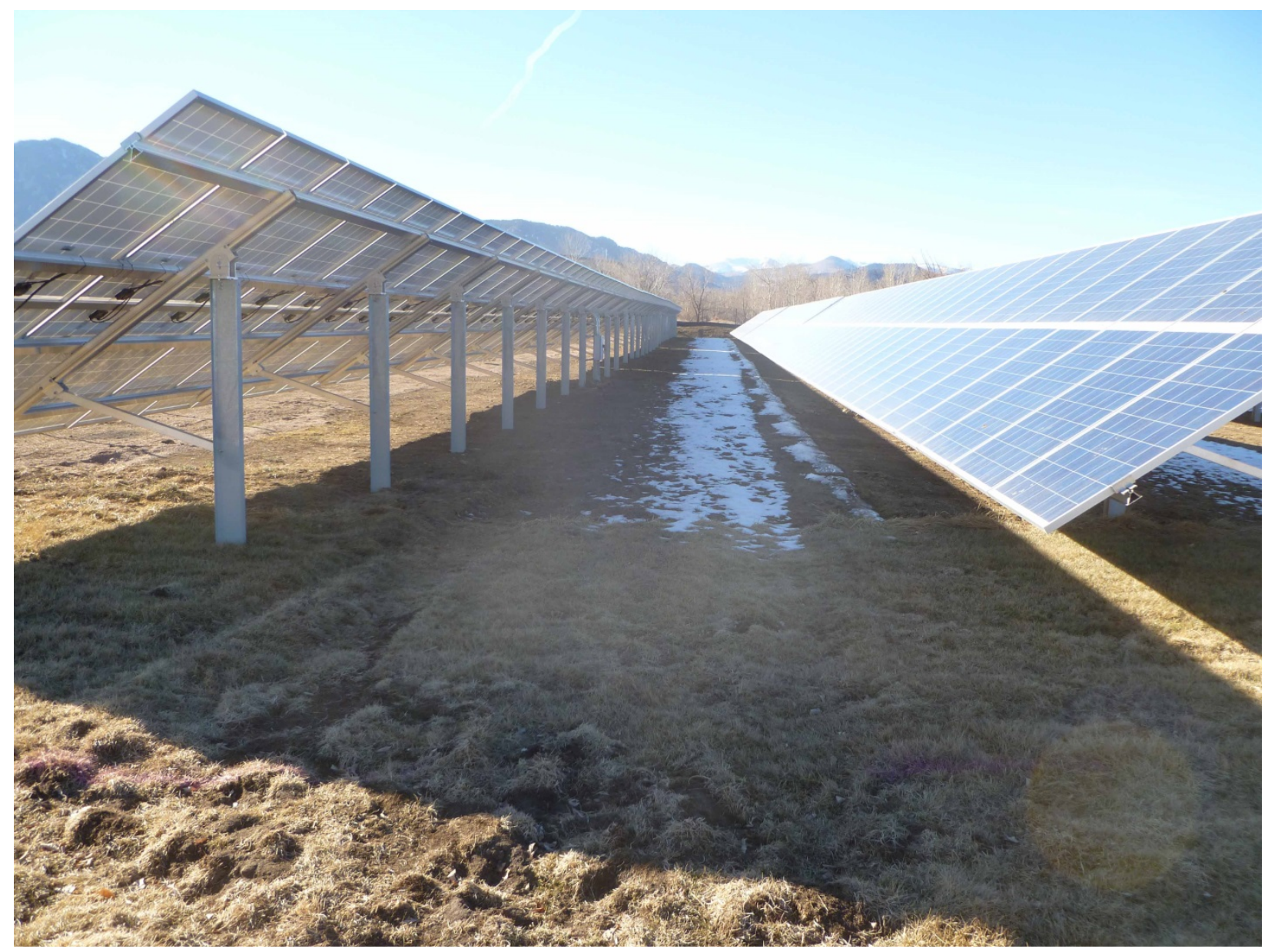

Photograph 11. Fixed panel photovoltaic array at University of Colorado East Campus, arranged in east-west rows, maximizing shading effects. View faces west. Photo Credit: Dave Buckner 


\section{Appendix B}

\section{NREL Test Plot Construction Sequence}

Step

\section{Description}

1. Use paint pencils to mark plot ID code on inner side of Northwest post

2. Rake all areas to roughen - work from drive-line backwards on both halves (North \& South)

3. Practice even distribution of seed/rice hulls* on plot size sample areas

4. Seed plots using appropriate pre-measured seed amount in cups

5. Rake in - working backwards as in Step 2

6. Place matting and anchor

7. Photograph plots

8. Install corner do-not-disturb signs.

* Rice hulls function as a "carrier" for very small seed, facilitating even spread of such fine particles. 